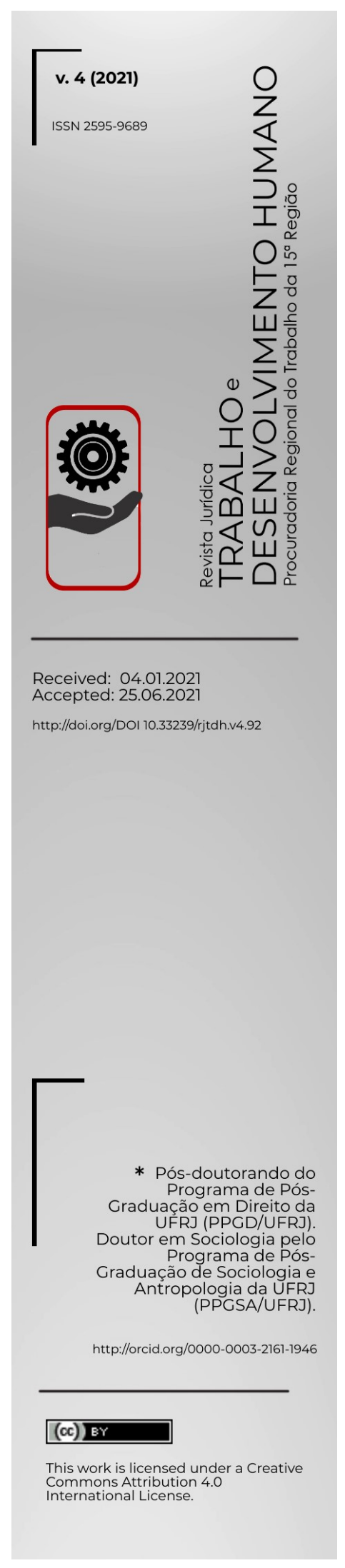

\title{
O tempo e o Direito do Trabalho no Brasil da pandemia de Covid-19: quatro teses inspiradas em François Ost ${ }^{1}$
}

\author{
Time and Labor Law in Brazil during the Covid-19 pandemic: \\ four theses inspired by François Ost
}

El tiempo y el Derecho del Trabajo en Brasil durante la pandemia de Covid19: cuatro tesis inspiradas en François Ost

\begin{abstract}
RESUMO
José Luiz Soares*

Trata-se de uma reflexão inspirada na teoria de François Ost sobre como a noção de tempo pode contribuir para pensar o Direito do Trabalho. São apresentadas quatro teses a respeito da relação entre o tempo e a situação do Direito do Trabalho no Brasil durante a pandemia de Covid-19: 1) O neoliberalismo vem subvertendo os sentidos conferidos pela Constituição Federal de 1988 para o ordenamento jurídico-político brasileiro e essa subversão teve um capítulo à parte durante a pandemia. 2) $O$ enfrentamento da pandemia se deu com uma grande aceleração do tempo jurídico, o que deteriorou o Direito do Trabalho. 3) Na conjuntura da pandemia, o choque entre diferentes temporalidades fomentou desigualdades e vulnerabilidades. 4) O neoliberalismo e a aceleração do tempo jurídico trouxeram sérios impactos para as possibilidades de mobilização coletiva e para a democracia. Para desenvolver a reflexão, foram analisadas medidas provisórias, leis trabalhistas, ações judiciais, estatísticas socioeconômicas, matérias jornalísticas e entrevistas com atores sociais selecionados.
\end{abstract}

PALAVRAS-CHAVE: Tempo. Direito do trabalho. Neoliberalismo. Pandemia.

\section{ABSTRACT}

The article proposes a reflection inspired by the theory of François Ost on how the notion of time can contribute to thinking about Labor Law. Four theses are presented about the relationship between the time and the situation of Labor Law in Brazil during the Covid-19 pandemic: 1) Neoliberalism has been subverting the meanings conferred by the Federal Constitution of 1988 for the Brazilian legal-political order and this subversion took place during the pandemic. 2) The confrontation of the pandemic occurred with a great acceleration of legal time, which deteriorated the Labor Law. 3) In the context of the pandemic, the clash between different temporalities fostered inequalities and vulnerabilities. 4) Neoliberalism and the acceleration of legal time have had a serious impact on the possibilities of collective mobilization and democracy. To develop the reflection, provisional measures, labor laws, lawsuits, socioeconomic statistics, journalistic articles and interviews with selected social actors were analyzed.

KEYWORDS: Time. Labor law. Neoliberalism. Pandemic.

\section{RESUMEN:}

Este artículo es una reflexión inspirada en la teoría de François Ost sobre cómo la noción de tiempo puede contribuir a la discusión sobre el Derecho del Trabajo. Se presentan cuatro tesis sobre la relación entre el tiempo y la situación del Derecho del Trabajo en Brasil durante la pandemia de Covid-19: 1) El neoliberalismo viene subvirtiendo los significados conferidos por la Constitución Federal de 1988 para el orden político-jurídico brasileño y esta subversión tuvo un capítulo aparte durante la pandemia. 2) El enfrentamiento contra la pandemia se dio con una gran aceleración del tiempo jurídico, lo que deterioró el Derecho del Trabajo. 3) En la coyuntura de la pandemia, el choque entre las diferentes temporalidades fomentó las desigualdades y vulnerabilidades. 4) El neoliberalismo y la aceleración del tiempo jurídico tuvieron graves repercusiones en las posibilidades de movilización colectiva y en la democracia. Para desarrollar esta reflexión, se analizaron medidas provisionales, leyes laborales, demandas judiciales, estadísticas socioeconómicas, artículos periodísticos y entrevistas con actores sociales seleccionados.

PALABRAS CLAVE: Tiempo. Derecho del trabajo. Neoliberalismo. Pandemia.

\footnotetext{
${ }^{1} \mathrm{O}$ artigo foi escrito a partir de debates realizados no âmbito dos grupos de pesquisa Configurações Institucionais e Relações de Trabalho (CIRT), coordenado por Sayonara Grillo; e Núcleo de Cultura Jurídica (NCJ), coordenado por Luiz Eduardo Figueira, ambos vinculados ao Programa de Pós-Graduação em Direito da UFRJ. Quaisquer erros ou insuficiências são de minha responsabilidade. A pesquisa contou com uma bolsa de pós-doutorado da CAPES.
} 


\section{INTRODUÇÃO}

O artigo é uma reflexão sobre como a noção de tempo, enquanto um fenômeno social e não meramente um fenômeno físico, pode contribuir para pensar os rumos do Direito do Trabalho no Brasil contemporâneo. A inspiração para refletir sobre as relações entre o tempo e o direito provém da teoria do jurista e filósofo François Ost. Partimos, mais especificamente, de seu conceito de destemporalização, espécie de "patologia temporal" que representa a dissolução dos tempos sociais instituídos e instituintes das relações sociais, processo este que se dá por meio do direito e das relações de poder. A ideia do direito como promotor da destemporalização, como um sistema de normas que não apenas institui e estabiliza os tempos sociais, mas que também provoca a desinstituição dessas temporalidades, foi mobilizada com o objetivo de refletir sobre o Direito do Trabalho no país, sobretudo no contexto da pandemia do novo coronavírus.

O exercício que fizemos foi o de pensar as configurações institucionais do direito do trabalho à luz de três diferentes formas de destemporalização: a da "continuidade petrificada" (ou determinismo), representada pelo neoliberalismo enquanto "pensamento único"; a da aceleração do tempo jurídico; e a do choque entre diferentes tempos sociais, que Ost chamou de discronia.

A proposição central que será apresentada nas linhas a seguir é a de que os rumos do Direito do Trabalho vêm sendo definidos pelo predomínio do neoliberalismo e que isso tem forte impacto em termos de destemporalização da vida social, bem como sobre as possibilidades de efetivação da justiça social e da democracia no país. Essa proposição será perseguida por meio de quatro teses que têm em comum a relação entre os tempos sociais e o direito trabalhista. Como fontes empíricas utilizamos medidas provisórias, leis trabalhistas, ações judiciais, estatísticas socioeconômicas, matérias jornalísticas e entrevistas com atores sociais selecionados.

O artigo está estruturado basicamente em cinco partes. Na primeira, são feitas breves considerações teóricas a respeito das relações entre o tempo e o direito segundo François Ost. As demais partes são compostas pela explanação das seguintes teses: 1) O neoliberalismo vem subvertendo os sentidos conferidos pela Constituição Federal de 1988 para o ordenamento 
jurídico-político brasileiro e essa subversão teve um capítulo à parte durante a pandemia. 2) O enfrentamento da pandemia se deu com uma grande aceleração do tempo jurídico, o que deteriorou o Direito do Trabalho. 3) Na conjuntura da pandemia, o choque entre diferentes temporalidades fomentou desigualdades e vulnerabilidades. 4) O neoliberalismo e a aceleração do tempo jurídico trouxeram sérios impactos para as possibilidades de mobilização coletiva e para a democracia.

\section{Breves notas sobre o tempo do direito, de François Ost}

A filosofia do direito de François Ost é um convite à reflexão sobre as relações possíveis entre o tempo e o direito. Segundo ele, existe entre ambos uma interação dialética profunda: o direito temporaliza, enquanto que o tempo determina a força instituinte do direito. ${ }^{2}$

A primeira parte dessa sentença (o direito temporaliza) quer dizer que o direito contribui para instituir o tempo das relações sociais. Note-se que o autor se refere mais propriamente ao tempo enquanto construção social do que enquanto um fenômeno físico ou

psíquico. É socialmente, pois, que se conta o tempo, se toma, se ganha, se gasta etc. Mas como o direito institui o tempo? Ost afirma que só é possível dizer o direito definindo temporalidades. Pense-se nos tempos de trabalho e de não-trabalho inscritos no direito laboral; nas definições temporais implícitas ao direito previdenciário; no prazo prescricional disciplinado pelo direito civil; ou ainda, na temporalidade dos ritos processuais. Pense-se igualmente no quanto as normas e os princípios jurídicos concorrem para os processos sóciotemporais da reprodução social e da mudança social. Esse ponto é fundamental. Ao passo que o direito e seus parâmetros normativos direcionam a vida cotidiana, orientam a resolução de conflitos, regulam a distribuição de bens pela sociedade e servem como elementos fundamentais para a construção de identidades, também contribuem para definir o que deve permanecer e o que deve mudar nas relações sociais.

A segunda parte da sentença (o tempo determina a força instituinte do direito) significa que a força que uma determinada lei possui só pode ser aferida por meio de sua

\footnotetext{
${ }^{2}$ OST, François. 0 tempo do direito. Tradução de Élcio Fernandes. Bauru: Edusc, 2005, p. 13.
} 
efetividade ao longo do tempo. O tempo é tido, dessa forma, como uma variável fundamental para avaliar a capacidade do direito de instituir a vida social, de ordená-la, de atar os laços sociais.

Em suma: o direito institui o tempo social, enquanto que o tempo revela a força instituinte do direito. Mas Ost adverte que a temporalidade instituinte sempre pode ser desfeita. Se pode instituir, o direito também pode, inversamente, desinstituir o tempo social, destemporalizar. ${ }^{3}$ Com a destemporalização, não apenas são desfeitos parâmetros normativos ordenadores dos tempos sociais mas também desatados laços sociais, cedendo espaço à formação de novos vínculos, com novos sentidos, ou apenas dando origem à desfiliação ${ }^{4}$, à vulnerabilidade e à insegurança social.

Segundo Ost, a definição dos processos sócio-temporais de instituição e desinstituição sempre envolve relações de poder. ${ }^{5}$ Detém poder aquele que consegue impor sua construção temporal a outros, seja instituindo novos laços sociais, seja desfazendo-os. Um exemplo fundamental do vínculo entre tempo e poder, considerando-se as finalidades do presente artigo, é a capacidade que os grandes agentes de mercado têm de impor sua temporalidade, de diversas maneiras, a pessoas, coletividades e Estados, num contexto de economia globalizada.

Feitas essas breves considerações teóricas iniciais, vamos às quatro teses sobre o tempo do Direito do Trabalho no Brasil na conjuntura da pandemia. Antes, apenas mais uma observação: as ações dos poderes públicos que incidiram sobre o Direito do Trabalho naquela conjuntura foram muito mais desinstituintes do que instituintes. Isso pode ser percebido pela suspensão de diversas normas e de princípios trabalhistas, deixando as relações de trabalho sujeitas em muitos casos a puras relações de força entre atores sociais com desiguais condições de poder. Pode ser percebido também pela precarização das condições de trabalho e pela fragilização dos laços sociais que teve vez no país. Por isso mesmo, as teses a seguir enfocam o caráter desinstituinte do Direito do Trabalho durante a pandemia, sua face destemporalizadora.

\footnotetext{
${ }^{3}$ OST, François. 0 tempo do direito. Tradução de Élcio Fernandes. Bauru: Edusc, 2005, p. 15.

${ }^{4}$ CASTEL, Robert. As metamorfoses da questão social. Petrópolis: Vozes, 1998.

${ }^{5}$ OST, François. 0 tempo do direito. Tradução de Élcio Fernandes. Bauru: Edusc, 2005, p. 25.
} 


\section{Primeira tese: 0 neoliberalismo vem subvertendo os sentidos conferidos pela Constituição} Federal de 1988 para o ordenamento jurídico-político brasileiro e essa subversão teve um capítulo à parte durante a pandemia.

Por neoliberalismo entende-se aqui um tipo de racionalidade e um sistema de normas que se caracterizam pela "generalização da concorrência como norma de conduta e da empresa como modelo de subjetivação" ${ }^{6}$. Não se trata, portanto, apenas de um tipo de política econômica que defende o Estado mínimo e o laissez-faire. O neoliberalismo assumiu, nas últimas quatro décadas, uma condição dominante em todas as esferas da vida social. Sua lógica da concorrência interindividual e de ação empresarial se tornou quase um imperativo para indivíduos e para o funcionamento das instituições. Está difundido pela cabeça de autoridades públicas, de empresários e de trabalhadores; está na forma como nos organizamos e em torno do quê.

A relação entre a racionalidade neoliberal e a questão da temporalização social é uma questão central aqui. É sabido que o neoliberalismo contribuiu para a aceleração do tempo econômico. Ou seja, para um padrão mais mutável dos processos de produção e de trabalho, das dinâmicas de mercado, dos padrões de consumo e das expectativas de lucro. Com efeito, autores de matizes diversas afirmam que o capitalismo das últimas décadas apresentou novas maneiras de organizar o tempo, migrando do longo prazo, típico do capitalismo fordistataylorista, para o curto prazo, radicalizando assim sua tendência histórica de transformar as condições de produção e de trabalho em busca de lucro. ${ }^{7}$

\footnotetext{
${ }^{6}$ DARDOT, Pierre; LAVAL, Christian. A nova razão do mundo. Tradução de Mariana Echalar. São Paulo: Boitempo, 2016, p. 17.

${ }^{7}$ Ver, por exemplo: HARVEY, David. Condição pós-moderna. Tradução de Adail Ubirajara Sobral e de Maria Stela Gonçalves. São Paulo: Loyola, 2008; BAUMAN, Zygmunt. Modernidade Líquida. Tradução de Plínio Dentzien. Rio de Janeiro: Zahar, 2001; SENNET, Richard. A corrosão do caráter: As consequências pessoais do trabalho no novo capitalismo. Rio de Janeiro: Record, 2005; BOLTANSKI, Luc; CHIAPELLO, Ève. O novo espírito do capitalismo. Tradução de Ivone C. Benedetti. São Paulo: Editora WMF Martins Fontes, 2009; e WAJCMAN, Judy. Digital technology, work extension and acceleration society. German Journal of Human Resource Management, v. 32, n. 03-04, maio. 2018.
} 
Mas esse processo histórico se relaciona com transformações sociais que vão para muito além da esfera econômica. Se a economia sob o signo do neoliberalismo - que é também a economia pós-fordista, financeirizada, em rede e globalizada - é demasiadamente acelerada e líquida, ela cobra de tudo ao redor de si que siga seu ritmo (o quanto obtém de êxito é outro assunto). Tudo deve mudar com fluidez: o direito, a política, as instituições, os laços sociais, os compromissos, as identidades. A mudança radical tornou-se "a coerção das coerções". ${ }^{8}$ A única permanência necessária seria a do próprio neoliberalismo. Os princípios neoliberais figuram então como uma espécie de eixo que busca monopolizar toda a possibilidade de permanência no tempo, ao passo que, com uma força centrípeta colossal, mantém toda uma roda-viva de mudanças em seu entorno.

Desde que deixou de ter o socialismo e a socialdemocracia como rivais à altura enquanto projetos de sociedade, o neoliberalismo conseguiu impor sua lógica sem rupturas efetivas. Nos termos de Ost, o tempo social do neoliberalismo é o da continuidade petrificada, do determinismo, espécie de destemporalização que se caracteriza pela recusa a projetos de futuro que não sejam os seus ${ }^{9}$, no caso aqueles que são ditados pela lógica de mercado.

Ost afirma que para que o tempo social seja de fato instituinte é preciso que haja um equilíbrio entre as dimensões temporais da continuidade e da ruptura. As forças instituintes conformam novos laços sociais e marcam uma ruptura com institutos consolidados. Mais cedo ou mais tarde, elas requisitam que esses mesmos laços também sejam desinstituídos. A continuidade petrificada representa, nesses termos, uma destemporalização na qual se recusa a dimensão da ruptura.

No contexto histórico de reinado absoluto do neoliberalismo, ganhou relevância analítica o uso do conceito de autoritarismo de mercado $^{10}$, aqui entendido como a imposição dos ditames dos grandes agentes de mercado por meio de mecanismos jurídico-políticos

\footnotetext{
${ }^{8}$ OST, François. O tempo do direito. Tradução de Élcio Fernandes. Bauru: Edusc, 2005, p. 32.

${ }^{9}$ OST, François. $O$ tempo do direito. Tradução de Élcio Fernandes. Bauru: Edusc, 2005, p. 30 et seq.

${ }^{10}$ Ver, por exemplo, HERNÁNDEZ, Adoración Guamán. Los desafíos del derecho internacional del trabajo: la OIT enfrentada a la Lex Mercatoria (en tiempos de Covid-19). Revista de Derecho Social, n. 90, abr. 2020.
} 
Revista Jurídica Trabalho e Desenvolvimento Humano Procuradoria Regional do Trabalho da 15a Região

criados e recriados de acordo com seus interesses e sua temporalidade, não raro alheios aos caminhos típicos de tomada de decisão democráticos. ${ }^{11}$

Quando muito, a temporalização petrificada permite variações do mesmo tema neoliberal. Segundo Ferreira12, estamos experimentando uma configuração específica do neoliberalismo desde a crise econômica global de 2008. O que a define são as políticas de austeridade, uma radicalização dos dogmas neoliberais que se materializa em propostas de enfrentamento a crises econômicas por meio de medidas de contenção no orçamento público e de profundas reformas legais, que implicam em desfazer pactos constitucionais, anular princípios e normas legais (com destaque para os que conformam o Direito do Trabalho), sempre em favor dos interesses do mercado. Tem vez assim um novo modelo jurídico: o direito de exceção. A excepcionalidade é parte intrínseca das políticas de austeridade e se justifica por meio de uma racionalidade instrumental de custo-benefício que afirma serem a contenção de gastos públicos e a erosão dos direitos sociais as únicas medidas realistas, lógicas e objetivas para superar um cenário de crise. There is no alternative! A legislação e o arcabouço protetivo em vigor são reduzidos a obstáculos para o bom funcionamento do mercado, que, sem eles, pode aprofundar seus padrões de acumulação flexível. Todo um discurso do medo de convulsões econômicas e sociais é evocado nas justificações das medidas de austeridade e de excepcionalidade ${ }^{13}$, ainda que venham a resultar em empobrecimento, aumento das desigualdades, vulnerabilidade, insegurança e sacrifício social, em franca contradição com princípios constitucionais.

Com as políticas de austeridade, os mecanismos por meio dos quais foi possível combinar o capitalismo e a democracia formal foram desestabilizados e substituídos por um tipo de sistema que se distancia radicalmente dos princípios democráticos. A democracia como aspiração por justiça social foi achatada. Verificou-se em quase todo o mundo uma desconstrução dos sistemas de proteção estatal e um enfraquecimento das entidades

\footnotetext{
${ }^{11}$ Como resumiu Slobodian, a respeito da pujança com que a esfera econômica se sobrepôs à política: "Politics had moved to the passive tense. The only actor was the global economy". SLOBODIAN, Quinn. Globalists: the end of empire and the birth of neoliberalism. Cambridge: Harvard University Press, 2018, p. 1.

12 FERREIRA, António Casimiro. The Politics of Austerity as Politics of Law. Oñati Socio-legal Series, v. 06, n. 03, set. 2016; e Sociedade da Austeridade e Direito do Trabalho de Exceção. Lisboa: Vida Econômica, 2012.

${ }^{13}$ PŘIBÁŇ, Jiří. Introduction: Theorizing Liquid Modernity and Its Legal Context. In: PŘıBÁŇ, Jiří (ed.). Liquid Society and Its Law. Aldershot: Ashgate, 2007, p. 01-14. (Tradução do autor)
} 
Revista Jurídica Trabalho e Desenvolvimento Humano Procuradoria Regional do Trabalho da 15ำ Região

coletivas de defesa dos direitos sociais. Com isso, reduziu-se substantivamente a participação dos trabalhadores na riqueza das nações. O rebaixamento da democracia social pode ser realizado dentro dos ritos típicos do Estado de Direito, mas não raro é imposto por meio de medidas políticas e jurídicas autoritárias, quando os agentes neoliberais encontram maiores resistências para implementar sua agenda. ${ }^{14}$

No Brasil, o Direito do Trabalho tem sido profundamente afetado nos últimos anos por políticas de austeridade e de exceção. ${ }^{15} \mathrm{~A}$ continuidade petrificada do neoliberalismo cobrou mudanças contínuas na esfera do direito. Antes da pandemia de Covid-19 e durante a mesma, o país experimentou ciclos de contrarreformas dos padrões de regulação do trabalho estabelecidos pela Constituição de 1988 e pela legislação infraconstitucional, protagonizados pelos três Poderes. Lado a lado com as contrarreformas, despontou no espaço público a face discursiva das políticas de austeridade. As reformas foram defendidas por autoridades públicas como medidas de modernização, desregulamentação, simplificação, desburocratização e de contenção de gastos, categorias estas que assumiram sentidos pretensamente positivos, objetivos e indiscutíveis. Era também um discurso salvacionista ante um Estado que, segundo diziam, estava quebrado e operando por meio de uma burocracia retrógada e corrupta.

Um marco nas políticas de austeridade e de exceção foi a Emenda Constitucional 95, aprovada no fim de 2016, no início do governo Temer, que instituiu um novo regime fiscal, com um teto para os gastos públicos nos próximos 20 anos. Outras mudanças normativas dignas de nota realizadas na mesma conjuntura política foram as reformas trabalhistas das

\footnotetext{
${ }^{14}$ Ver SLOBODIAN, Quinn. Globalists: the end of empire and the birth of neoliberalism. Cambridge: Harvard University Press, 2018; DARDOT, Pierre; LAVAL, Christian. A nova razão do mundo. Tradução de Mariana Echalar. São Paulo: Boitempo, 2016; e KLEIN, Naomi. A doutrina do choque: a ascensão do capitalismo de desastre. Tradução de Vania Cury. Rio de Janeiro: Nova Fronteira, 2008.

${ }^{15}$ A deposição da presidenta Dilma Rousseff, em agosto de 2016, foi um ponto de inflexão na trajetória de avanço da austerização no Brasil. Para esse tema e demais assuntos sobre as políticas de austeridade e de exceção nos últimos anos no país, ver SILVA, Sayonara Grillo Coutinho da; EMERIQUE, Lilian Balmant; BARISON, Thiago (orgs.). Reformas institucionais de austeridade, democracia e relações de trabalho. São Paulo: LTr, 2018; CAVALLAZZI, Rosângela Lunardelli; SILVA, Sayonara Grillo Coutinho Leonardo da. Políticas de austeridade no Brasil contemporâneo: retrocessos laborais e consumeristas (2017-2019). Revista de Direito do Consumidor, ano 28, v. 126, nov./dez. 2019; FREITAS, Carlos Eduardo Soares; OLIVEIRA, Murilo Carvalho Sampaio; DUTRA, Renata Queiroz (orgs.). Reforma Trabalhista e Crise do Direito do Trabalho no Brasil: Apontamentos Críticos. Curitiba: Appris, 2020; e KREIN, José Dari; OLIVEIRA, Roberto Véras de; FILGUEIRAS, Vitor Araújo (orgs.). Reforma trabalhista no Brasil: promessas e realidade. Campinas: Curt Nimuendajú, 2019.
} 
Revista Jurídica Trabalho e Desenvolvimento Humano Procuradoria Regional do Trabalho da 15a Região

Leis no $13.429 / 2017$ e 13.467/2017 16 e as ações julgadas no Supremo Tribunal Federal (STF) que ampliaram a permissão jurídica para uso das terceirizações nas relações de trabalho no Brasil - a ADPF 324 e a RE 958.252 ${ }^{17}$. Por um lado, essas medidas representaram a flexibilização ou supressão de direitos trabalhistas; por outro, criaram medidas que inibem a ação de instituições reguladoras das relações de trabalho, em especial os sindicatos e a Justiça do Trabalho.

O enredo se manteve durante o governo Bolsonaro. Antes da pandemia, um novo ciclo de agenda de austeridade e exceção foi implementado, vide a extinção do Ministério do Trabalho, Emprego e Previdência (MTE), por meio da Medida Provisória (MP) 870; a revisão de diversas Normas Regulamentadoras de Segurança e Saúde no Trabalho (NR's) por iniciativas do governo federal; a Declaração de Direitos de Liberdade Econômica (Lei no 13.874), que estabeleceu um conjunto de garantias de livre mercado; a reforma da previdência (EC 103), que, ademais, alimentou reformas para alterar as regras de aposentadorias de estados e municípios; e, por fim, o Contrato de Trabalho Verde e Amarelo (MP 905), que teve validade entre novembro de 2019 e abril de 2020, período em que desonerou contratos de trabalho, tornando-os mais baratos para os empresários.

As medidas jurídico-políticas de austeridade e de exceção tiveram continuidade no contexto da pandemia de Covid-19. ${ }^{18}$ A crise sanitária e econômica foi enfrentada no Brasil principalmente com medidas político-legais que rebaixaram as garantias trabalhistas para proporcionar maior segurança jurídica para as empresas desenvolverem suas estratégias de acumulação. Para tanto, houve contribuições dos três poderes. Todo um direito de emergência surgiu para o enfrentamento da crise, com medidas provisórias, leis, decretos, portarias e sentenças judiciais que, carregando o signo da urgência, da provisoriedade e da

\footnotetext{
${ }^{16}$ Ver KREIN, José Dari; OLIVEIRA, Roberto Véras de; FILGUEIRAS, Vitor Araújo (orgs.). Reforma trabalhista no Brasil: promessas e realidade. Campinas: Curt Nimuendajú, 2019.

17 Ver DUTRA, Renata; MATOS, Bianca. A Terceirização, o STF e o Estado de Exceção. Teoria Jurídica Contemporânea, ano 04, v. 02, jul./dez. 2019; e VANONI, Luciana Muniz. As disputas narrativas no direito e a terceirização no direito do trabalho. Dissertação (Mestrado em Direito). Universidade Estácio de Sá, Rio de Janeiro, 2019.

${ }^{18}$ Para fins de análise, tomamos como marco inicial o dia 11 de março de 2020, quando a Organização Mundial da Saúde caracterizou a Covid-19, doença causada pelo novo coronavírus, como uma pandemia. Por outro lado, a presente análise se refere apenas aos acontecimentos ocorridos no contexto brasileiro até novembro de 2020.
} 
exceção, suspenderam a eficácia de regras trabalhistas, subverteram princípios constitucionais e reduziram a margem de ação de instituições de regulação laboral.

Os fatos mais relevantes nesse sentido por parte do Poder Executivo provieram de diversas medidas provisórias com efeitos sobre a esfera do trabalho. As MPs continham claros dispositivos de exceção, que retiraram direitos, aumentaram riscos e resultaram em perdas econômicas para os trabalhadores. Dentre os dispositivos mais relevantes estiveram: a prevalência do acordo individual sobre as leis trabalhistas e sobre as normas negociadas coletivamente, as restrições à fiscalização do trabalho, a antecipação de férias e de feriados e a previsão da implantação do teletrabalho sem necessidade de alteração no contrato de trabalho, instituídas pela MP 927; a previsão da possibilidade de suspensão temporária de contratos de trabalho, assim como da redução de jornada e de salários, instituídas pela MP 936; a permissão para contratar empregados em substituição a trabalhadores avulsos nos portos nacionais e a ampliação do rol de atividades previstas como essenciais na lei de greve (Lei no 7.783/89), instituídas pela MP 945; e a permissão de saque parcial do FGTS, oriunda da MP 946, que trouxe consigo o risco de esvaziar as reservas públicas destinadas a realizar políticas de apoio social aos trabalhadores. O repertório de políticas de austeridade e de exceção promovidas pelo governo Bolsonaro durante a pandemia também foi composto pela publicação de portarias do Ministério da Economia. Vide a Portaria no 16.655/2020, que disciplinou a hipótese de recontratação de empregados nos casos de rescisão sem justa causa realizada durante a pandemia, deixando de ser consideradas fraudes as recontratações nesses termos realizadas em período inferior a noventa dias subsequentes à data da rescisão contratual.

O Legislativo Federal, por sua vez, procurou acelerar o tempo de tramitação das medidas provisórias, tanto na Câmara quanto no Senado ${ }^{19}$, e apresentou grande empenho em converter a MP 936 naquela que veio a ser promulgada como Lei $n$ ㅇ 14.020/2020, instituindo o Programa Emergencial de Manutenção do Emprego e da Renda. Vale frisar que, a despeito

\footnotetext{
${ }^{19}$ BRASIL. Ato Conjunto das Mesas da Câmara dos Deputados e do Senado Federal no 1, de 2020. Dispõe sobre o regime de tramitação, no Congresso Nacional, na Câmara dos Deputados e no Senado Federal, de medidas provisórias durante a pandemia de Covid-19. Diário Oficial da União, Atos do Congresso Nacional, Brasília, DF, 01 abr. 2020. Seção 1, p. 1. Disponível em: <https://www.in.gov.br/en/web/dou/-/ato-conjunto-das-mesas-dacamara-dos-deputadose-do-senado-federal-n-1-de-2020-250639870>. Acesso em: 31 jul. 2020.
}

SOARES, José Luis. O tempo e o Direito do Trabalho no Brasil da pandemia de Covid-19: quatro teses inspiradas em François Ost. Revista Jurídica Trabalho e Desenvolvimento Humano, Campinas, v. 4, p. 1-35, 2021. 
Revista Jurídica Trabalho e Desenvolvimento Humano Procuradoria Regional do Trabalho da 15ำ Região

do título, o Programa Emergencial resultou em perdas econômicas e de outros direitos para os trabalhadores.

Já no Poder Judiciário, os julgamentos das ações que questionaram a constitucionalidade de artigos da MP 927 (Ações Diretas de Inconstitucionalidade 6342, 6344, 6346, 6348, 6349, 6352 e 6354) e da MP 936 (ADI 6363) despertaram a interpretação, no debate doutrinário, de que se produziu ali uma espécie de direito de exceção. No primeiro caso, os pedidos cautelares de declaração de inconstitucionalidade de artigos da MP 927 foram todos indeferidos por decisão monocrática do relator, o ministro Marco Aurélio Mello. Em um segundo momento, o plenário do STF deferiu a cautelar em parte, mas suspendeu a eficácia apenas dos artigos 29 e 31 da referida MP (os quais, respectivamente, desconsideravam os casos de infecção de trabalhadores pelo novo coronavírus como doença ocupacional e limitavam a atuação de auditores fiscais do trabalho à atividade de orientação). No caso da ADI 6363, com relatoria do ministro Ricardo Lewandowski, o tribunal indeferiu a medida cautelar integralmente. Alguns dos dispositivos cuja eficácia foi conservada - como o artigo 2 으 MP 927, que afirma a preponderância do acordo individual sobre as leis trabalhistas e sobre os contratos coletivos de trabalho - têm o potencial de inverter o sistema de hierarquias do Direito do Trabalho, em prejuízo dos trabalhadores, e embora os ministros tenham argumentado que buscaram compatibilizar os valores sociais do trabalho e a livre iniciativa nos marcos da Constituição, parecem bem razoáveis as interpretações de que suas decisões infringiram direitos fundamentais. ${ }^{20}$

Ainda sobre a atuação do STF durante a pandemia, cumpre mencionar a liminar deferida pelo ministro Gilmar Mendes para a Ação Declaratória de Constitucionalidade 58, proposta pela Confederação Nacional do Sistema Financeiro (Consif), e que suspendeu todos

\footnotetext{
${ }^{20}$ Ver GARCIA, Gustavo Filipe Barbosa. Prevalência de acordo individual sobre coletivo é questionável. Conjur, 2020. Disponível em: https://www.conjur.com.br/2020-mai-13/gustavo-garcia-acordo-individual-acordocoletivo. Acesso em: 05 jul. 2020; GARCIA, Gustavo Filipe Barbosa. Respeito à Constituição em situações de crise: redução salarial em decisão do STF. Conjur, 2020. Disponível em: https://www.conjur.com.br/2020-abr27/barbosa-garcia-respeito-constituicao-situacoes-crise. Acesso em: 05 jul. 2020; SANTOS, Ana Clara Paiva; PEREIRA, langre; DINIZ, Ana Paola. A relevância da intervenção sindical e da negociação coletiva em tempos de Covid-19: uma análise crítica das Medidas Provisórias 927 e 936/2020 sob a ótica dos julgamentos do STF. In: Hirsch, Fábio Periandro (org.). Covid-19 e o Direito na Bahia. Salvador: Editora Direito Levado a Sério, 2020, p. 123-149; e DELGADO, Gabriela Neves; AMORIM, Helder Santos. A legislação pandêmica e o perigoso regime de exceção aos direitos fundamentais trabalhistas. Revista Jurídica Trabalho e Desenvolvimento Humano, v. 3, 2020. Disponível em: http://revistatdh.org/index.php/Revista-TDH/article/view/80. Acesso em: 14 dez. 2020.
}

SOARES, José Luis. O tempo e o Direito do Trabalho no Brasil da pandemia de Covid-19: quatro teses inspiradas em François Ost. Revista Jurídica Trabalho e Desenvolvimento Humano, Campinas, v. 4, p. 1-35, 2021. 
Revista Jurídica Trabalho e Desenvolvimento Humano Procuradoria Regional do Trabalho da 15ำ Região

os processos que envolviam correção monetária de créditos trabalhistas. A controvérsia sobre aplicação da Taxa Referencial (TR) 21 ou do IPCA-E (Índice de Preço ao Consumidor Ampliado Especial) como índice de correção paralisou milhares de processos na Justiça do Trabalho ${ }^{22}$, em fase de conhecimento ou de execução, e produziu efeitos deletérios para milhões de pessoas.

Tudo somado, fica notório que as políticas neoliberais resultaram em um agudo processo de destemporalização no Brasil da pandemia, com a corrosão de normas trabalhistas e de princípios constitucionais. Não obstante o discurso neoliberal de que o estado de emergência provocado pela pandemia de Covid-19 justificaria soluções duras e que as políticas de austeridade e exceção seriam o único remédio possível para o cenário de crise, as experiências de enfrentamento à pandemia em outros países demonstram que havia alternativas. Em países como a Argentina e a Espanha, por exemplo, o reconhecimento de direitos trabalhistas e sindicais foi parte fundamental das políticas governamentais de enfrentamento da pandemia. ${ }^{23}$ A proteção e a garantia da subsistência daqueles-que-vivemdo-trabalho foi fundamental para proporcionar as condições para que o maior número possível de pessoas se mantivesse em isolamento social, ao menos nos primeiros meses da pandemia. A inspiração para adotar medidas alternativas poderia provir igualmente da Organização Internacional do Trabalho (OIT), que recomendava a adoção de medidas coordenadas e de grande escala que apoiassem o emprego e a renda, protegessem os trabalhadores nos locais de trabalho e estimulassem a economia. ${ }^{24}$

\footnotetext{
${ }^{21}$ A Taxa Referencial (TR) foi criada em 1991, em um contexto de hiperinflação, para ser usada no cálculo de remuneração de operações de crédito. Posteriormente, foi usada para a atualização monetária de créditos trabalhistas e veio a ser muito questionada por isso, uma vez que a TR acumula variações muito abaixo dos índices de inflação, como o IPCA.

${ }^{22}$ O STF já havia firmado jurisprudência que negava a adoção da TR para correção de valores reconhecidos na justiça (ADIs 4357 e 4425 e RCL 22012). Porém, a Lei no 13.467/2017 insistiu na adoção da mesma como critério e realimentou a controvérsia. Na época da liminar de Gilmar Mendes, o pleno do TST também vinha analisando o tema. Dos 27 ministros do tribunal, 17 já haviam declarado a inconstitucionalidade do uso da TR, com 16 deles definindo o IPCA-E como índice para corrigir dívidas trabalhistas.

${ }^{23}$ Ver FILLEUL, Rodrigo Méndez; PELIZA, Eleonora. Efectos del Covid-19 en las relaciones laborales en América Latina: Argentina. Revista IDEIDES, n. 50, jul. 2020; e AHUMADA, Eduardo López. Medidas de protección laboral y de seguridad social aplicadas en España durante el estado de alarma provocado por la epidemia del Covid-19. Revista Actualidad Laboral, abr. 2020.

${ }^{24}$ OIT - ORGANIZAÇÃO INTERNACIONAL DO TRABALHO. Covid-19 and world of work: Impacts and responses. Publicado pela OIT em 18 de março de 2020. Disponível em: https://www.ilo.org/global/about-theilo/WCMS 738753/lang--en/index.htm. Acesso em: 13 jul. 2020. (Tradução do autor)
} 
Revista Jurídica Trabalho e Desenvolvimento Humano Procuradoria Regional do Trabalho da 15ำ Região

Por aqui, o mais próximo disso que tivemos foi a Lei $\mathrm{n}$ - 13.982, que instituiu a Renda Básica de Cidadania Emergencial, sem dúvida uma medida importante para garantir dignidade a milhões de pessoas e que teve importância para a mitigação dos efeitos da crise econômica; e também a MP 936 (depois convertida em Lei no 14.020/2020) e a MP 944, que instituíram programas emergenciais com o objetivo declarado de manter emprego e renda. De todo modo, os efeitos dessas medidas foram limitados. De acordo com a Pesquisa Nacional por Amostra de Domicílios Contínua - PNAD Contínua (IBGE), o desemprego no Brasil vem atingindo níveis recordes desde o início da pandemia. Em setembro, o país chegou ao patamar de 14,1 milhões de desempregados ${ }^{25}$ (1,8 milhão a mais que em fevereiro) e de 5,9 milhões de desalentados ${ }^{26}$ (1,2 milhão a mais que em fevereiro). A taxa de desocupação ${ }^{27}$ ficou em 14,6\% (em fevereiro estava em 11,6\%), a maior da série histórica, que se inicia em 2012. Por outro lado, a pesquisa Pulso Empresa, também do IBGE, demonstrou que até a primeira quinzena de junho de 2020 , cerca de $32,6 \%$ das empresas do país encerraram suas atividades temporária (15\%) ou definitivamente $(17,6 \%) .{ }^{28}$ Neste cenário, tudo indica que as medidas governamentais não foram suficientes para garantir ao conjunto dos trabalhadores não apenas trabalho e renda, mas também as condições ideais para se manterem em isolamento social ${ }^{29}$, ainda que o auxílio emergencial tenha tido impacto positivo entre os mais vulneráveis.

É preciso questionar o quanto as medidas jurídico-políticas remediaram ou agravaram as consequências econômicas do cenário pandêmico. O futuro trará análises mais categóricas, mas desde já é possível inferir que as políticas de enfrentamento da pandemia no Brasil, com

\footnotetext{
${ }^{25}$ De acordo com a metodologia usada pelo IBGE na PNAD Contínua, os desempregados (ou desocupados) são as pessoas com idade para trabalhar (acima de 14 anos) que não estão trabalhando, mas estão disponíveis e tentam encontrar trabalho. Isso exclui tanto os que estão sem trabalho mas, por algum motivo, não procuram por um, quanto os empreendedores que possuem seu próprio negócio.

${ }^{26}$ De acordo com a metodologia usada pelo IBGE na PNAD Contínua, os desalentados são pessoas que gostariam de trabalhar e estão disponíveis, porém, por algum motivo, desistiram de procurar trabalho.

${ }^{27}$ A taxa de desocupação (ou taxa de desemprego) da PNAD Contínua corresponde à porcentagem de pessoas desocupadas na força de trabalho (soma de ocupados e desocupados dentre a população acima de 14 anos).

${ }^{28}$ Infelizmente, esses dados foram disponibilizados pelo IBGE nos levantamentos da Pulso Empresa somente até a primeira quinzena de junho. IBGE - Instituto Brasileiro de Geografia e Estatística. Pesquisa Pulso Empresa: Impacto da Covid-19 nas empresas. Publicado pelo IBGE em 16 de julho de 2020. Disponível em: https://agenciadenoticias.ibge.gov.br/media/com mediaibge/arquivos/548281f191c80ecbbb69846b0d745eb5 .pdf. Acesso em: 17 jul. 2020.

${ }^{29}$ Ver REDE DE PESQUISA SOLIDÁRIA. Covid-19: Políticas Públicas e as Respostas da Sociedade. Boletim, n. 15, 10 jul. 2020.
} 
austeridade e exceção, não foram positivas nem do ponto de vista humanitário (no que tange a manter as pessoas na segurança do isolamento social) nem do econômico (com manutenção de empregos e sustentação de empresas).

3 Segunda tese: 0 enfrentamento da pandemia se deu com uma grande aceleração do tempo jurídico, o que deteriorou o Direito do Trabalho.

A temporalidade da mudança radical, da mobilidade e da flexibilidade se tornou algo cada vez mais fundamental na modernidade. ${ }^{30} \mathrm{Na}$ esfera jurídica, seus impactos foram profundos. Segundo François Ost, o imperativo da mudança chegou mesmo a levar o direito, nos últimos anos, a um novo paradigma. Migrou de um modelo linear, duradouro e previsível a outro, que é recursivo, reversível e incerto.

A lei não é mais um acontecimento, mas um processo, não é mais um ato, mas um programa, não trabalha mais através de disposições, mas através de previsão, não estabelece mais instituições, elabora cenários, não impõe mais normas, abre opções. O que ela perde em segurança e normatividade, busca compensar em adaptabilidade e flexibilidade. ${ }^{31}$

A produção do direito estaria, assim, passando por uma aceleração, por uma temporalidade exageradamente móvel, em que o longo prazo é negado de muitas maneiras. A lei feita de dia é desfeita de noite. A reinvenção é contínua. A reforma, um estado permanente.

Ademais, se por um lado a produção do direito acelerada proporciona insegurança jurídica, por outro, o mundo institucional que ele ajuda a construir é também exageradamente móvel e essencialmente instável. Nesse cenário, o direito se enfraquece e, por consequência, induz um efeito de precarização e erosão da coesão social. A condição de vida da maioria dos indivíduos tende à insegurança ontológica e à vulnerabilidade social.

Há profundas raízes econômicas na aceleração do tempo jurídico teorizada por Ost. Nos dias de hoje, lobistas poderosos operam em meio às afinidades eletivas entre a economia e o direito. Eles assediam regimes democráticos e, em favor de interesses particulares, incitam

\footnotetext{
${ }^{30}$ BAUMAN, Zygmunt. Modernidade Líquida. Tradução de Plínio Dentzien. Rio de Janeiro: Zahar, 2001.

${ }^{31}$ OST, François. $O$ tempo do direito. Tradução de Élcio Fernandes. Bauru: Edusc, 2005, p. 305.
} 
um movimento de constante desfazer e refazer do direito. Frequentemente logram impor sua temporalidade, o que deve permanecer e o que deve mudar no mundo das leis e das relações econômicas, assim como o ritmo em que as mudanças devem se dar. Essa dinâmica jurídicoeconômica tem como guia a racionalidade neoliberal. Se o neoliberalismo representa, nos termos de Ost, o tempo social da continuidade petrificada, existe em contrapartida um conjunto de forças que impelem tudo o mais ao seu redor à mudança, se adequando a seus princípios lógicos e aos interesses de mercado, na velocidade que melhor convier.

O sociólogo António Casimiro Ferreira faz análise semelhante no que diz respeito à associação entre tempo e direito. ${ }^{32}$ Dentre as várias fases e configurações históricas da relação tempo-direito que ele identifica, estaríamos experimentando uma configuração específica desde a crise econômica de 2008, que une a aceleração do tempo jurídico e as políticas de austeridade. Resultaria daí um duplo movimento de vulnerabilização social. A instabilidade institucional, a insegurança jurídica e a fragilização social decorrentes da aceleração do tempo jurídico somam-se à desconstrução dos direitos sociais, ao empobrecimento e ao endividamento que têm origem nas políticas de austeridade. O paradigma jurídico dominante que emerge dessa relação tempo-direito é o do direito de exceção, que se caracteriza pela transformação das regras jurídicas em ritmo muito acelerado e pela suspensão sucessiva de normas e de princípios constitucionais. No campo específico do trabalho, as políticas de austeridade e de exceção resultam em precarização dos direitos laborais, com suspensão de mecanismos protetivos e fragilização da ação coletiva da classe trabalhadora.

O que tivemos no Brasil durante a pandemia de Covid-19 foi algo semelhante. Chamou a atenção o fato de que seu enfrentamento não se deu apenas por meio de instrumentos jurídicos-legais previamente existentes. Houve uma produção aceleradíssima de novas regras do trabalho. Somente entre os dias 22 de março e 07 de abril de 2020, em 16 dias portanto, foram editadas sete medidas provisórias com efeitos sobre o Direito do Trabalho: a MP 927, de 22 de março, dispôs sobre medidas trabalhistas para enfrentamento da pandemia; a MP 928, de 23 de março, revogou o artigo da MP 927 que definia a possibilidade do contrato de trabalho ser suspenso por até quatro meses durante a pandemia; a MP 936, de 01을 de abril,

\footnotetext{
32 FERREIRA, António Casimiro. The Politics of Austerity as Politics of Law. Oñati Socio-legal Series, v. 06, n. 03, set. 2016; e Sociedade da Austeridade e Direito do Trabalho de Exceção. Lisboa: Vida Econômica, 2012.
}

SOARES, José Luis. O tempo e o Direito do Trabalho no Brasil da pandemia de Covid-19: quatro teses inspiradas em François Ost. Revista Jurídica Trabalho e Desenvolvimento Humano, Campinas, v. 4, p. 1-35, 2021. 
Revista Jurídica Trabalho e Desenvolvimento Humano Procuradoria Regional do Trabalho da 15ำ Região

instituiu o Programa Emergencial de Manutenção do Emprego e da Renda; a MP 937, de 02 de abril, criou uma linha de crédito extraordinário para o pagamento do auxílio emergencial instituído pela Lei no 13.982; a MP 944, de 03 de abril, instituiu o Programa Emergencial de Suporte a Empregos; a MP 945, de 04 de abril, dispôs sobre medidas temporárias de resposta à pandemia no âmbito do setor portuário; e, por fim, a MP 946, de 07 de abril, dentre outras providências, extinguiu o Fundo PIS-Pasep, transferindo seu patrimônio para o Fundo de Garantia do Tempo de Serviço. A esse conjunto de medidas provisórias se soma a promulgação da Lei no 13.982, de 02 de abril, que instituiu a Renda Básica de Cidadania Emergencial. O conjunto dessas medidas legais conformaram uma espécie de regulação de emergência, que trouxe consigo toda uma instabilidade jurídico-legal para o mundo do trabalho (legislativa, jurisprudencial e nas negociações coletivas), com precarização de direitos laborais e limitações para a atuação das organizações de regulação do trabalho.

Um exemplo prático de como a aceleração do tempo jurídico pode desestabilizar uma atuação institucional é dado pelas condições de atuação dos auditores fiscais do trabalho ${ }^{33}$ durante a pandemia de Covid-19. Como dito por um auditor fiscal ${ }^{34}$, ao se referir aos reflexos da reorganização administrativa que teve vez com a extinção do Ministério do Trabalho, Emprego e Previdência (MTE), incorporando-o ao Ministério da Fazenda:

O que aconteceu no ano passado com o tal projeto de unificação - que eles chamaram de Projeto Unifica - foi que parte da estrutura administrativa da Superintendência Regional do Trabalho do Rio de Janeiro, os servidores administrativos seriam realocados no novo Ministério, na nova estrutura. (...) Aí a gente perdeu vários setores. E eu tive problemas básicos de enfrentamento da crise que passaram por problemas de estrutura, de unificação que não foi dada a cabo de fato. Quando você concentra, faz uma concentração e coloca os servidores lá, você tem que ter um mínimo de organização. (...) Mas a gente vê uma grande confusão na organização da estrutura regional. A minha primeira dúvida é o organograma, porque eu preciso saber das competências. (...) Não houve um organograma na hora da unificação. (...) Mais do que uma angústia, isso causa uma desorganização administrativa. Isso teve reflexos também em alguns problemas que a gente passou com a pandemia de Covid-19.

\footnotetext{
${ }^{33}$ Os auditores fiscais do trabalho são funcionários públicos com incumbência de inspeção do trabalho a fim de assegurar a aplicação das leis e dos regulamentos existentes para a proteção dos trabalhadores. Suas atividades são consideradas pela OIT como de essencial importância para o sistema de regulação do trabalho. A organização legal da carreira dos auditores fiscais do trabalho é estabelecida pela Lei no 10.593, de 06 de dezembro de 2002. ${ }^{34}$ Entrevista realizada remotamente, via Google Meet, em 17 de novembro de 2020.
} 
O fenômeno da aceleração do tempo jurídico aliada às políticas de austeridade tem um histórico que antecede a pandemia. Cavallazzi e Silva ${ }^{35}$, por exemplo, já vinham demonstrando os efeitos da aceleração do tempo jurídico sobre os direitos trabalhistas e consumeristas no Brasil dos últimos anos. A novidade durante a pandemia talvez tenha sido apenas a intensidade altíssima com que se deram as contrarreformas legais. Mas, há décadas vem sendo muito repetida, no espaço público no Brasil, a tese de que a legislação trabalhista é um impeditivo ao bom funcionamento da economia, uma vez que influenciaria negativamente os processos de compra e venda da força de trabalho, dificultaria a competitividade empresarial num contexto de economia globalizada e bloquearia a criação de empregos. Como a legislação trabalhista é convertida em uma variável negativa para toda a economia, um cenário de crise justificaria a sua modernização, simplificação, desburocratização. Esses argumentos foram imperativos também durante a pandemia, quando o enfrentamento de uma crise de natureza ao mesmo tempo sanitária e econômica justificou a criação de um direito de emergência deletério. Interessante perceber que, embora a legislação trabalhista tivesse sido modernizada recentemente, ainda assim, novos sacrifícios seriam necessários e justificados.

A crise desponta como uma oportunidade. A situação faz lembrar uma famosa sentença que diz que a crise econômica é uma companheira de viagem histórica do Direito do Trabalho. ${ }^{36}$ A questão que fica é o quanto a retórica da austeridade utiliza-se de um senso de urgência ante um cenário de crise como um mecanismo de legitimação para reformar o Direito do Trabalho. Como diz Ferreira ${ }^{37}$, as políticas de austeridade costumam produzir o caos e oferecer como remédio uma certa perspectiva de ordem, a qual só pode ser promovida por meio de contrarreformas que suprimem direitos. Essas políticas se alimentam do caos. Sem sua negatividade não há a pretensa positividade do ordenamento da austeridade. A criação

\footnotetext{
35 CAVALLAZZI, Rosângela Lunardelli; SILVA, Sayonara Grillo Coutinho Leonardo da. Políticas de austeridade no Brasil contemporâneo: retrocessos laborais e consumeristas (2017-2019). Revista de Direito do Consumidor, ano 28, v. 126, nov./dez. 2019. (Tradução do autor)

36 LÓPEZ, Manuel-Carlos Palomeque. Un compañero de viaje historico del derecho del trabajo: la crisis economica. Revista de Política Social, n. 143, jul./set. 1984.

${ }^{37}$ FERREIRA, António Casimiro. The Politics of Austerity as Politics of Law. Oñati Socio-legal Series, v. 06, n. 03, set. 2016; e Sociedade da Austeridade e Direito do Trabalho de Exceção. Lisboa: Vida Econômica, 2012.
}

SOARES, José Luis. O tempo e o Direito do Trabalho no Brasil da pandemia de Covid-19: quatro teses inspiradas em François Ost. Revista Jurídica Trabalho e Desenvolvimento Humano, Campinas, v. 4, p. 1-35, 2021. 
do direito de exceção é facilitada pelo medo das consequências da crise. Nessas ocasiões, o medo, a legitimação e a exceção se encontram e se reforçam mutuamente.

4 Terceira tese: Na conjuntura da pandemia, o choque entre diferentes temporalidades fomentou desigualdades e vulnerabilidades.

Segundo a filosofia do direito de François Ost, para que a justiça social e a solidariedade tenham vez em uma determinada sociedade é preciso que seus membros minimamente marchem no mesmo passo, que seus ritmos temporais sejam minimamente coordenados. É preciso também que existam mecanismos de coordenação da pluralidade de ritmos temporais, para os quais é fundamental algum tipo de política de Estado e alguma regulação jurídica. Na ausência de mecanismos que sincronizem os ritmos, acumulam-se tensões entre as mais diversas temporalidades: a do trabalho versus a do não-trabalho; a do trabalho produtivo versus a do trabalho reprodutivo; a de ganhadores versus a de excluídos; a das trocas financeiras versus a da produção; a da produção versus a da regeneração do meio ambiente; a da comunicação de massa versus a da maturação da reflexão etc. Em suma, se os ritmos temporais de indivíduos e de coletividades seguem sem coordenação, o que resta é a discronia, é o choque entre diferentes tempos sociais.

A discronia resulta em graves lesões ao direito de indivíduos e de coletividades terem seu próprio tempo. É um fenômeno intrinsecamente relacionado às desigualdades e às vulnerabilidades sociais. No limite, a discronia combina-se muito bem com um cenário de puras relações de força, onde reina absoluta a temporalidade imposta por quem detém poder. Segundo Ost:

...a sincronização dos ritmos sociais tornou-se um dos fatores mais
importantes da regulação: quer se trate de dividir o tempo de trabalho,
redistribuir a alocação do tempo livre e do tempo profissional, de repensar a
solidariedade entre jovens ativos e pessoas idosas, de regular as velocidades
do crescimento entre regiões do globo, ou ainda impor as condições para um
desenvolvimento duradouro, em cada caso é de sincronia que se trata. ${ }^{38}$

${ }^{38}$ OST, François. 0 tempo do direito. Tradução de Élcio Fernandes. Bauru: Edusc, 2005, p. 38.

SOARES, José Luis. O tempo e o Direito do Trabalho no Brasil da pandemia de Covid-19: quatro teses inspiradas em François Ost. Revista Jurídica Trabalho e Desenvolvimento Humano, Campinas, v. 4, p. 1-35, 2021. 
Revista Jurídica Trabalho e Desenvolvimento Humano Procuradoria Regional do Trabalho da 15aㅡ Região

Note-se que tanto o direito de indivíduos e coletividades terem seu próprio tempo quanto a atuação dos poderes públicos como coordenadores da pluralidade de ritmos temporais são profundamente afetados pela racionalidade neoliberal e pela aceleração do tempo jurídico, examinadas acima. O neoliberalismo por fragilizar a capacidade reguladora dos Estados e por contribuir para a renovação das técnicas de controle sobre o tempo dos indivíduos. A aceleração do tempo jurídico por desestabilizar os tempos sociais e produzir vulnerabilidades, ao passo que o direito é desfeito e refeito.

Pensemos a situação do Direito do Trabalho no Brasil da pandemia sob a ótica da teoria da discronia. É forçoso ter em conta os múltiplos ritmos temporais existentes nesse contexto, bem como o que houve de coordenação entre as diferentes temporalidades de percepção e de vulnerabilidade ao risco. Nesse sentido, a fim de promover a principal medida de combate à Covid-19, qual seja o isolamento social, fazia-se necessário que os poderes públicos assegurassem as condições econômicas e jurídicas para que o maior número de trabalhadores pudesse permanecer em casa. Contudo, a condução da economia e a articulação entre os diferentes fluxos temporais foram definidas pelos poderes públicos segundo o modelo das políticas de austeridade e de exceção. Isso significa que os poderes públicos direcionaram suas ações menos no sentido de garantir oportunidades de subsistência e de sincronizar temporalidades num cenário de crise, e mais no sentido de garantir segurança jurídica para a reprodução do grande capital e de sua maneira de gerir o tempo dos negócios.

O quanto a temporalidade dos grandes interesses econômicos foi favorecida pode ser presumido pelo enriquecimento significativo de um pequeno grupo de capitalistas durante a pandemia ${ }^{39}$, ao passo que centenas de milhares de pequenos negócios faliram e milhões de trabalhadores perderam trabalho e renda, quando não a própria vida. Há uma associação possível entre o alto número de vítimas da Covid-19, o perfil do capitalismo ultraliberal à

\footnotetext{
${ }^{39}$ Segundo a Oxfam International, o patrimônio de 42 bilionários do Brasil passou de US\$123,1 bilhões para US\$ 157,1 bilhões entre 18 de março e 12 de julho. Ver G1. Patrimônio dos super-ricos brasileiros cresce US\$ 34 bilhões durante a pandemia, diz Oxfam. Portal G1, 27 de jul. de 2020. Disponível em: <https://g1.globo.com/economia/noticia/2020/07/27/patrimonio-dos-super-ricos-brasileiros-cresce-us-34bilhoes-durante-a-pandemia-diz-oxfam.ghtml>. Acesso em: 28 de jul. de 2020; e OXFAM INTERNACIONAL. Poder, lucros e a pandemia: da distribuição excessiva de lucros e dividendos de empresas para poucos para uma economia que funcione para todos. Relatório de Pesquisa. Publicado pela Oxfam Brasil em setembro de 2020. Disponível em: https://www.oxfam.org.br/justica-social-e-economica/poder-lucros-e-pandemia/. Acesso em: 20 set. 2020 .
} 
brasileira e o problema da discronia. Primeiro porque o modelo econômico e as grandes corporações no Brasil priorizaram o lucro em detrimento da segurança dos trabalhadores e do enfrentamento à pandemia. Some-se a isso que as políticas públicas não garantiram as melhores condições para os trabalhadores se manterem em isolamento social. ${ }^{40} \mathrm{O}$ trabalho e a circulação para o trabalho se tornaram um dos principais vetores de infecção pelo novo coronavírus. ${ }^{41}$ Pode-se deduzir a partir daí que as políticas de austeridade e de exceção foram responsáveis em grande medida por uma realidade de crise, precariedade e vulnerabilidade social. Estão na origem da crise, mas também demonstraram ser incapazes de responder a ela. Como Harvey vem argumentando, o capitalismo é o maior problema e não a pandemia. ${ }^{42}$

Mas cumpre ressaltar ainda como a discronia está envolvida nessa equação. O ponto fundamental é que a fragilização dos mecanismos protetivos do trabalho e a instabilidade institucional oriunda da aceleração do tempo jurídico representam para as relações sociais uma maior imposição das temporalidades dos dominantes. O controle capitalista sobre os tempos de trabalho e de não-trabalho, as políticas de emprego e renda, bem como as definições temporais implícitas no direito previdenciário vêm sendo profundamente alterados nos últimos anos por contrarreformas trabalhistas e previdenciárias. Surgiram novas modalidades de contratação; diversificaram-se as formas de organizar a jornada de trabalho e a remuneração; a dispensa do trabalho foi (ainda mais) facilitada; o tempo médio de gozo dos benefícios previdenciários foi reduzido. Nesse ínterim, os trabalhadores tornaram-se menos donos de seu tempo. Com a pandemia de Covid-19, esse processo social teve um capítulo à parte, considerando-se o cenário de crise, a retirada de direitos, o tempo jurídico aceleradíssimo e o aumento do desemprego. A potencialização da discronia pode ser observada em muitas situações. Citemos alguns exemplos.

\footnotetext{
${ }^{40}$ Ver REDE DE PESQUISA SOLIDÁRIA. Covid-19: Políticas Públicas e as Respostas da Sociedade. Boletim, n. 15, 10 jul. 2020.

${ }^{41}$ Ver MARINO, Aluizio; KLINTOWITZ, Danielle; BRITO, Gisele; ROLNIK, Raquel; SANTORO, Paula; MENDONÇA, Pedro. Circulação para trabalho explica concentração de casos de Covid-19. Uol - A cidade é nossa, 2020. Disponível em: https://raquelrolnik.blogosfera.uol.com.br/2020/06/30/circulacao-para-trabalho-explicaconcentracao-de-casos-de-covid-19/. Acesso em: 07 jul. 2020.

42 HARVEY, David. Value in motion. New Left Review, n. 126, nov./dez. 2020; e Política anticapitalista em tempos de COVID-19. In: DAVIS, Mike et al. Coronavírus e a luta de classes. S/I: Terra sem Amos, 2020, p. 13-23.
} 
1) Se a pandemia afetou a todos, de uma maneira ou de outra, analistas dos mais diversos campos do conhecimento vêm chamando a atenção para o fato de que seus efeitos foram desiguais, com marcadores de vulnerabilidade de classe, gênero, cor e idade.

Uma abordagem a partir do conceito de pobreza de tempo ${ }^{43}$ ajuda a pensar o fenômeno. O conceito remete à ideia de que as condições de pobreza devem ser analisadas sob um ponto de vista multidimensional, não se resumindo à privação de renda. Assim, os pobres de tempo são aqueles que não conseguem destinar tempo suficiente para atividades como emprego (desocupados, desalentados, subocupados por insuficiência de horas trabalhadas), descanso, lazer, educação, formação profissional, cuidados com a saúde e a participação em espaços de poder. O conceito se aplica particularmente bem para pensar as interseções entre as desigualdades de classe, gênero e cor, que correspondem aos grupos mais afetados pela escassez de tempo. Também pode servir para pensar a pobreza de tempo como um resultado da discronia ou do choque entre a temporalidade de grupos dominantes e dominados.

Deduz-se daí que os mais pobres de tempo foram especialmente afetados pela pandemia de Covid-19, ou seja, que o enfraquecimento dos direitos laborais, os cortes de jornada de trabalho e de salários e o aumento do desemprego os atingiram com maior força. É prova disso o fato de que os trabalhadores que ganhavam de 1 a 2 salários mínimos foram os mais atingidos por fechamento de vagas formais durante a pandemia (ao menos até maio de 2020). Segundo o Novo Caged, cerca de $77 \%$ das vagas fechadas até maio pagavam salários mensais nessa faixa. ${ }^{44}$ Ademais, pesquisas com outros enfoques apontam que a perda de empregos no período pandêmico foi mais acentuada entre mulheres, negros e jovens do que entre homens, brancos e adultos. ${ }^{45}$

\footnotetext{
43 DAMIÁN, Araceli. La pobreza de tiempo. Una revisión metodológica. Estudios demográficos y urbanos, v. 18, n. 01, jan./abr. 2003.

${ }^{44}$ Cf. CAVALLINI, Marta. Com pandemia, fechamento de vagas formais atinge mais quem ganha de 1 a 2 salários mínimos. G1, 12 de jul. de 2020. Disponível em: <https://g1.globo.com/economia/concursos-eemprego/noticia/2020/07/12/com-pandemia-fechamento-de-vagas-formais-atinge-mais-quem-ganha-de-1-a2-salarios-minimos.ghtml>. Acesso em: 12 de jul. de 2020. Cumpre ressaltar que os dados acima, referentes ao saldo de vagas de trabalho por salário mensal, não foram compilados e apresentados nas Estatísticas Mensais do Emprego Formal - Novo Caged. Eles foram enviados pela Secretaria Especial de Previdência e Trabalho ao G1 atendendo a pedidos.

${ }^{45}$ Ver GÊNERO E NÚMERO \& SOF - SEMPREVIVA ORGANIZAÇÃO FEMINISTA. Sem Parar: o trabalho e a vida das mulheres na pandemia. Publicado pela REMIR - Rede de Estudos e Monitoramento Interdisciplinar da Reforma
} 
Revista Jurídica Trabalho e Desenvolvimento Humano Procuradoria Regional do Trabalho da 15a Região

2) Outro exemplo de potencialização da discronia e da pobreza de tempo pela pandemia do novo coronavírus diz respeito ao trabalho reprodutivo. Sem ter onde deixar os filhos, uma miríade de trabalhadoras perdeu o emprego ou o abandonou para cuidar da família e ainda enfrentaram sobrecarga de tarefas domésticas. A taxa de participação de mulheres com filhos de até 10 anos no mercado de trabalho caiu de $58,3 \%$ no segundo trimestre de 2019 para 50,6\% no mesmo período de $2020 .{ }^{46}$ Por outro lado, há indícios de que as mulheres foram mais afetadas pela pandemia que os homens no que diz respeito aos trabalhos domésticos - vide a pesquisa online realizada entre abril e maio pela Fiocruz (Fundação Oswaldo Cruz) com mais de 40 mil pessoas. ${ }^{47}$ Dentre as mulheres, 26,4\% afirmaram que o trabalho doméstico aumentou muito, ao passo que apenas $13,1 \%$ dos homens disseram o mesmo.

3) A escalada da discronia e da pobreza de tempo durante o período pandêmico também pode ser aferida por variações na jornada de trabalho em diversos setores da economia. Se milhões de trabalhadores tiveram seu tempo de trabalho produtivo reduzido, inclusive com a perda do emprego, outros tantos experimentaram uma ampliação na jornada de trabalho.

O estudo sobre trabalho remoto/home-office durante a pandemia coordenado por Bridi $^{48}$ demonstra a existência de um aumento de horas diárias trabalhadas e de dias trabalhados semanalmente desde que fora adotada a modalidade de trabalho remoto. A faixa

\footnotetext{
Trabalhista em 03 de agosto de 2020. Disponível em: https://www.eco.unicamp.br/remir/images/Artigos 2020/Relatorio Pesquisa SemParar.pdf. Acesso em: 20 ago. 2020; e BARBOSA, Ana Luiza de Holanda; COSTA, Joana Simões; HECKSHER, Marcos. Mercado de Trabalho e Pandemia da Covid-19: Ampliação de Desigualdades já Existentes? Mercado de trabalho: conjuntura e análise / Instituto de Pesquisa Econômica Aplicada, ano 26, v. 01, jul. 2020.

${ }^{46}$ BASILIO, Patrícia. Com creches fechadas na pandemia, participação de mulheres no mercado de trabalho é a menor desde 1990. G1, 05 de set. de 2020. Disponível em: <https://g1.globo.com/economia/concursos-eemprego/noticia/2020/09/05/com-creches-fechadas-na-pandemia-participacao-de-mulheres-no-mercado-detrabalho-e-a-menor-desde-1990.ghtml>. Acesso em: 05 de set. de 2020.

47 ESTUDO da Fiocruz mostra que mulheres são mais afetadas pela pandemia. Rede Brasil Atual, São Paulo, 27 de mai. de 2020. Disponível em: <https://www.redebrasilatual.com.br/cidadania/2020/05/estudo-fiocruzmulheres-pandemia/>. Acesso em: 27 de mai. de 2020.

${ }^{48}$ BRIDI, Maria Aparecida; BOHLER, Fernanda Ribas; ZANONI, Alexandre Pilan. O Trabalho Remoto/Home-Office no Contexto da Pandemia Covid-19 - Parte I. Relatório de Pesquisa. Publicado pela REMIR - Rede de Estudos e Monitoramento Interdisciplinar da Reforma Trabalhista em 24 de julho de 2020. Disponível em: https://www.eco.unicamp.br/remir/images/Artigos 2020/RELATRIO DE DIVULGAO DA PESQUISA SOBRE O TRABALHO REMOTO.pdf. Acesso em: 26 jul. 2020.
} 
de trabalhadores que executam suas atividades laborais por mais de 8 horas diárias variou de $16,11 \%$, antes da pandemia, para $34,44 \%$, durante a mesma. Em relação aos dias trabalhados semanalmente, antes da pandemia, 8,39\% de trabalhadores disseram que desempenhavam suas atividades laborais em 6 dias por semana; essa proporção aumentou para 18,10\% durante a pandemia. Da mesma forma, dentre os que trabalharam 7 dias por semana, o número variou de $2,32 \%$ para $17,77 \%$.

4) De outra parte, entre os entregadores de empresas de aplicativos, categoria que ganhou bastante visibilidade durante a pandemia, muito se reclamou de aumentos de jornada de trabalho associados a quedas de rendimento. ${ }^{49} \mathrm{~A}$ jornada de trabalho dos entregadores de empresas de aplicativos foi ampliada e a sua remuneração reduzida justamente quando estes se tornaram essenciais, por distribuírem alimentos, remédios e outras mercadorias compradas pela Internet ou por telefone. Com a demanda em alta, as principais empresas do setor ampliaram a quantidade de entregadores nas ruas, o que acirrou a concorrência por corridas e deu ensejo à diminuição dos valores pagos.

O uso da tecnologia dos aplicativos e a forma de contratação de trabalho a que os entregadores estão submetidos, a modalidade intermitente - que foi formalizada pela reforma trabalhista da Lei no 13.467/2017 -, dão novos contornos à questão do controle capitalista sobre o tempo de trabalho. Os aplicativos permitem uma conexão instantânea entre empresas e trabalhadores, que são acionados de acordo com o ritmo da demanda e remunerados por serviços prestados. Os entregadores ficam à disposição da temporalidade das empresas de uma maneira mais flexível e intensa do que em formas de contratação mais convencionais. Tornam-se menos donos de seu tempo. Não raro isso representa jornadas longas e com muitos tempos vagos. Também é comum que recebam um montante mensal a título de remuneração menor que o salário mínimo. ${ }^{50}$

\footnotetext{
${ }^{49}$ OLIVEIRA, Murilo Carvalho Sampaio; SANTOS, Tácio da Cruz; ROCHA, Wendy Santos. Os entregadores das plataformas digitais: controvérsias judiciais, autonomia, dependência e controle. Direito.UnB, v. 04, n. 02, mai.ago. 2020; NEVES, lanaira Barretto; SUTIL, Bruno. Algocracia e a racionalidade Neoliberal: Uma reflexão a partir da greve dos entregadores de aplicativos. Paper apresentado no 13을 Congresso Latino Americano de Varejo e Consumo - CLAV 2020, São Paulo, out. 2020. Publicado pela FGV - Fundação Getúlio Vargas. Disponível em: https://clav2020.fgv.br/. Acesso em: 24 nov. 2020.

${ }^{50}$ KREIN, José Dari; OLIVEIRA, Roberto Véras de; FILGUEIRAS, Vitor Araújo (orgs.). Reforma trabalhista no Brasil: promessas e realidade. Campinas: Curt Nimuendajú, 2019.
} 
Revista Jurídica Trabalho e Desenvolvimento Humano

Procuradoria Regional do Trabalho da 15ำ Região

5 Quarta tese: 0 neoliberalismo e a aceleração do tempo jurídico trouxeram sérios impactos para as possibilidades de mobilização coletiva e para a democracia.

Os processos jurídicos, políticos e sociais abordados acima se afastam dos princípios democráticos de muitas maneiras. Primeiramente pelo que as medidas provisórias editadas para responder à crise pandêmica representaram em termos de direito constitucional. Elas não apenas retiraram direitos trabalhistas, mas alguns de seus dispositivos apresentaram o potencial de desfazer o princípio protetivo do Direito do Trabalho - vide o artigo 20 da MP 927, que estabelece a prevalência do acordo individual sobre as leis trabalhistas e sobre as normas negociadas coletivamente. Embora o STF tenha examinado a constitucionalidade dessas medidas provisórias e decidido conservar a eficácia das mesmas quase integralmente, muito se debateu nos meios jurídicos sobre o quanto elas infringiram direitos fundamentais. ${ }^{51}$

Um segundo motivo pelo qual a democracia foi impactada diz respeito ao quanto a difusão do neoliberalismo dificulta a realização de mobilizações coletivas. Conforme os indivíduos experimentem a lógica da concorrência em todas as esferas da vida social, as próprias possibilidades de construção da ação coletiva são afetadas. No contexto da pandemia, esse problema pôde ser percebido, por exemplo, pelas limitações às mobilizações dos entregadores de aplicativos trazidas por uma autoimagem difundida entre muitos deles de que são empresários de si mesmos. Nas palavras de um expoente dos movimentos reivindicatórios dos entregadores ${ }^{52}$ :

\footnotetext{
51 Vide, por exemplo, GARCIA, Gustavo Filipe Barbosa. Prevalência de acordo individual sobre coletivo é questionável. Conjur, 2020. Disponível em: https://www.conjur.com.br/2020-mai-13/gustavo-garcia-acordoindividual-acordo-coletivo. Acesso em: 05 jul. 2020; GARCIA, Gustavo Filipe Barbosa. Respeito à Constituição em situações de crise: redução salarial em decisão do STF. Conjur, 2020. Disponível em: https://www.conjur.com.br/2020-abr-27/barbosa-garcia-respeito-constituicao-situacoes-crise. Acesso em: 05 jul. 2020; SANTOS, Ana Clara Paiva; PEREIRA, langre; DINIZ, Ana Paola. A relevância da intervenção sindical e da negociação coletiva em tempos de Covid-19: uma análise crítica das Medidas Provisórias 927 e 936/2020 sob a ótica dos julgamentos do STF. In: Hirsch, Fábio Periandro (org.). Covid-19 e o Direito na Bahia. Salvador: Editora Direito Levado a Sério, 2020, p. 123-149; e DELGADO, Gabriela Neves; AMORIM, Helder Santos. A legislação pandêmica e o perigoso regime de exceção aos direitos fundamentais trabalhistas. Revista Jurídica Trabalho e Desenvolvimento Humano, v. 3, 2020. Disponível em: http://revistatdh.org/index.php/RevistaTDH/article/view/80. Acesso em: 14 dez. 2020.

52 Entrevista com Paulo Lima, o Galo, membro dos Entregadores Antifascistas, realizada por Jorge Luiz Souto Maior e Rodrigo Carelli em 30 de junho de 2020. Resenha Trabalhista Especial: Pelo que lutam os entregadores e o que temos com isso? Disponível em: https://www.youtube.com/watch?v=u0ifxhL1LZg. Acesso em: 03 de jul. de 2020.
} 
Não foram os Entregadores Antifascistas que iniciaram a greve. A greve surgiu da maneira dela. A greve se iniciou de uma revolta coletiva. O Brasil está estranho... Os entregadores não se enxergam como trabalhadores. É uma greve, mas não é uma greve de pessoas que na sua maioria se enxergam como trabalhadores. Os caras têm o sentimento de não querer partido político envolvido. Tem gente já falando que se for preciso vai rasgar bandeira. Aquela história, sabe? Eu apoio a greve porque a gente tem um sofrimento em comum. E eu não sou dos caras que ficam esperando o tempo ideal pra sair. Vou pra luta com o que tem. A greve rejeitou a interlocução com trabalhadores de outras categorias. Os Entregadores Antifascistas não. Nós tá junto com os metroviários. Os caras vai parar também, mano. Meu sentimento é da classe trabalhadora, no geral, unida. Mas a greve não quer misturar as coisas.

A racionalidade neoliberal - que se manifesta no senso de empreendedorismo e em outros mecanismos cognitivos e morais - corrói as coletividades, enfraquece a substância e os tipos de subjetividades necessários para as mobilizações coletivas, quais sejam, de um lado, o compartilhamento de sensos de (in)justiça, sentimentos e interesses; e, de outro, formas de agregação colaborativas que se constituem com o intuito de defender o reconhecimento desses mesmos sensos de justiça, sentimentos e interesses. ${ }^{53}$

Além disso, a racionalidade neoliberal promove o enfraquecimento de espaços de cidadania. As MPs 927 e 936 são exemplos disso. Elas trazem dispositivos que fragilizam organizações defensoras dos direitos trabalhistas como os sindicatos e as auditorias fiscais do trabalho, uma vez que afirmam a prevalência do acordo individual em relação a leis e normas negociadas coletivamente; impõem restrições à fiscalização do trabalho; preveem a possibilidade de redução de jornada e de salários e a suspensão temporária de contratos de trabalho etc.

Outro motivo pelo qual a democracia foi afetada é o fato de que, como diz François Ost, quando a esfera jurídica passa por uma aceleração da produção legal, a capacidade instituinte da vida social pelo direito se enfraquece, abrindo espaço para puras relações de força. Assim, pois, as normas trabalhistas instituídas na conjuntura da pandemia surgiram tão velozmente que é de se esperar que uma parcela substantiva dos trabalhadores sequer tenha

\footnotetext{
${ }^{53}$ Ver HONNETH, Axel. Luta por reconhecimento. A gramática moral dos conflitos sociais. São Paulo: Editora 34, 2003; e, de um outro ponto de vista teórico, CEFAï, Daniel. Como nos mobilizamos? A contribuição de uma abordagem pragmatista para a sociologia da ação coletiva. Dilemas - Revista de Estudos de Conflito e Controle Social, v. 2, n. 4, abr./jun. 2009.
} 
chegado a tomar conhecimento das mesmas até ser gravemente afetada. A aceleração do tempo jurídico contraria as temporalidades da concepção dos problemas públicos, da construção das ações coletivas e da institucionalização dos conflitos, elementos fundamentais para a efetivação dos direitos. A democracia necessita de uma temporalidade relativamente aberta à mudança, que permita a renovação de direitos, mas também que não seja um tempo exageradamente móvel, do contrário são interditados os tempos da problematização das relações sociais, do debate, da difusão de informações, da construção de interesses coletivos, da negociação, dos controles legais e cidadãos. ${ }^{54} \mathrm{~A}$ aceleração corrói a tudo isso, dificultando as mobilizações coletivas e a realização dos ritos democráticos.

Por fim, é possível dizer que a democracia foi afetada também pelo aumento da discronia e das desigualdades sociais durante a pandemia. O ponto aqui é que as políticas de austeridade resultam em pobreza e precariedade com tanta intensidade, que é forçoso questionar o quanto uma democracia suporta efetivamente esses efeitos negativos. Como diz Ferreira, vivemos num contexto histórico em que a democracia como aspiração por justiça social está sendo trocada pela democracia como regime meramente formal. ${ }^{55} \mathrm{O}$ título de regime democrático é reivindicado nos espaços públicos ainda que direitos constitucionais sejam desrespeitados, que os espaços de cidadania diminuam e que a pobreza e as desigualdades sociais sejam fomentadas.

\footnotetext{
${ }^{54}$ Antes da pandemia, o problema da aceleração do tempo jurídico para os ritos democráticos foi gritante por ocasião do processo legislativo que resultou na Lei no 13.467. O projeto de lei enviado pelo Poder Executivo ao Congresso Nacional alterava apenas sete artigos da CLT, mas foi transformado em uma peça com mais de cem alterações, em um processo legislativo bastante acelerado. Os dispositivos ali contidos não foram objeto de debates públicos satisfatórios, embora afetassem profundamente a regulação do trabalho e as negociações coletivas no Brasil. Sobre a rapidez com que a Lei n. 13.467/2017 tramitou e foi aprovada no Congresso Nacional, sem diálogo ou concertação social relevante, ver MASSAU, Guilherme; BAINY, André. Diálogo social, pacto social, reforma trabalhista e a proibição do retrocesso: um contrassenso prenunciado. Revista Jurídica Trabalho e Desenvolvimento Humano, v. 3, 2020. Disponível em: https://www.revistatdh.org/index.php/RevistaTDH/article/download/61/42. Acesso em: 14 dez. 2020.

${ }^{55}$ FERREIRA, António Casimiro. The Politics of Austerity as Politics of Law. Oñati Socio-legal Series, v. 06, n. 03, set. 2016.
} 


\section{CONSIDERAÇÕES FINAIS}

Ao longo do artigo procurou-se refletir sobre como as relações entre o tempo e o direito podem contribuir para a compreensão da situação do Direito do Trabalho no Brasil durante a pandemia. A abordagem, inspirada na teoria de François Ost, resultou em quatro teses. As três primeiras dizem respeito a diferentes formas de desinstituição dos tempos sociais por meio do direito. A última tese refere-se a como esses processos sociais desinstituintes resultaram em lesões à democracia.

A primeira e principal forma de destemporalização dos tempos sociais abordada é o determinismo com que a racionalidade neoliberal vem se impondo ao longo do tempo, inclusive ao longo da pandemia. Há aí uma espécie de temporalidade da continuidade petrificada, que recusa questionamentos, ao passo que cobra do direito uma constante transformação para se adequar à lógica e à moralidade neoliberal. A desinstituição dos tempos sociais se dá, nesse caso, por meio de sucessivas reformas nas normas e nos princípios jurídicos para que se adequem aos dogmas de mercado. A segunda forma de destemporalização é a aceleração do tempo jurídico, que ocorre quando a esfera jurídica passa por uma aceleração da produção legal. Trata-se de um processo desinstituinte porque, quando o Direito do Trabalho faz-se exageradamente móvel, além da possibilidade sempre presente da perda de direitos, acontece que os parâmetros normativos vigentes perdem (ao menos em parte) a força de instituir o social. Consequentemente, os laços sociais de solidariedade - antes atados pelo direito - são corroídos, resultando em desfiliação, vulnerabilidade e insegurança social. A última forma de destemporalização é caracterizada pelo choque entre diferentes temporalidades e ritmos sociais, ao qual Ost chama de discronia. Nesse caso, a desinstituição se dá por meio da prevalência da temporalidade dos dominantes sobre a dos dominados, retirando desses últimos o direito a ter seu próprio tempo. Trata-se de um fenômeno intrinsecamente relacionado às desigualdades e às vulnerabilidades sociais.

Como dito acima, o desenrolar desses processos desinstituintes no decorrer da pandemia lesaram o que há de democracia no Brasil de muitas maneiras: infringindo direitos fundamentais, dificultando as mobilizações coletivas, enfraquecendo os espaços de cidadania, aprofundando as desigualdades sociais etc. O ponto central foi que o domínio da racionalidade 
neoliberal entre representantes dos poderes públicos fez com que os direitos ao trabalho, à saúde e à vida fossem considerados verdadeiros obstáculos a serem superados para que as estratégias empresariais em meio à crise pandêmica se desenvolvessem a contento (do grande empresariado). As políticas públicas de emergência produzidas em resposta à pandemia assumiram esse sentido. Contudo, elas não tiveram bons resultados, nem do ponto de vista sanitário nem do econômico.

A reflexão a partir das relações entre tempo e direito proporciona assim um direcionamento crítico. Primeiramente ao neoliberalismo, isto é, à lógica da vida social como uma empresa concorrencial e a suas consequências deletérias. É fundamental cultivar uma memória coletiva da falibilidade das políticas e dos pressupostos neoliberais. Se os resultados trágicos do neoliberalismo não forem rememorados, problematizados e combatidos, o que teremos no pós-pandemia é uma reprodução sem freios do movimento de precarização dos direitos sociais, com consequências igualmente deletérias.

Além da crítica ao neoliberalismo, a reflexão a partir das relações entre tempo e direito aponta para a necessidade de desaceleração do tempo jurídico e de coordenação dos tempos sociais, a fim de possibilitar que os tempos do direito e da política sejam mais virtuosos, assim como de evitar a discronia e seus riscos. Nesse ínterim, as proteções sociais podem ser repensadas de modo a que os imperativos da mudança e da flexibilidade na esfera do trabalho não se traduzam automaticamente em precariedade.

Por ora é preciso ter claro que os abalos de uma pandemia ou de crises financeiras sempre têm um impacto nas sociedades, mas a natureza e a profundidade desse impacto dependem das concepções que orientam o funcionamento do direito, da economia e da política. Nesse ínterim, ao invés de um obstáculo para o enfrentamento de um contexto de crise, o Direito do Trabalho poderia ser melhor compreendido como um aliado, fundamental por exemplo para viabilizar o isolamento social e, consequentemente, para amenizar os efeitos da pandemia e ativar a economia. As questões dos mundos do direito, da saúde e da economia podem caminhar juntas. 


\section{REFERÊNCIAS}

AHUMADA, Eduardo López. Medidas de protección laboral y de seguridad social aplicadas en España durante el estado de alarma provocado por la epidemia del Covid-19. Revista Actualidad Laboral, abr. 2020.

BARBOSA, Ana Luiza de Holanda; COSTA, Joana Simões; HECKSHER, Marcos. Mercado de Trabalho e Pandemia da Covid-19: Ampliação de Desigualdades já Existentes? Mercado de trabalho: conjuntura e análise / Instituto de Pesquisa Econômica Aplicada, ano 26, v. 01, jul. 2020.

BASILIO, Patrícia. Com creches fechadas na pandemia, participação de mulheres no mercado de trabalho é a menor desde 1990. G1, 05 de set. de 2020. Disponível em: <https://g1.globo.com/economia/concursos-e-emprego/noticia/2020/09/05/com-crechesfechadas-na-pandemia-participacao-de-mulheres-no-mercado-de-trabalho-e-a-menordesde-1990.ghtml>. Acesso em: 05 de set. de 2020.

BAUMAN, Zygmunt. Modernidade Líquida. Tradução de Plínio Dentzien. Rio de Janeiro: Zahar, 2001.

BOLTANSKI, LUC; CHIAPELLO, Ève. O novo espírito do capitalismo. Tradução de Ivone C. Benedetti. São Paulo: Editora WMF Martins Fontes, 2009.

BRASIL. Ato Conjunto das Mesas da Câmara dos Deputados e do Senado Federal no 1, de 2020. Diário Oficial da União, Atos do Congresso Nacional, Brasília, DF, 01 abr. 2020. Seção 1 , p. 1. Disponível em: $<$ https://www.in.gov.br/en/web/dou/-/ato-conjunto-das-mesas-dacamara-dos-deputadose-do-senado-federal-n-1-de-2020-250639870>. Acesso em: 31 jul. 2020.

BRASIL. Emenda Constitucional no 95, de 15 de dezembro de 2016. Brasília, DF: Presidência da República, [2016]. Disponível em:

http://www.planalto.gov.br/ccivil 03/constituicao/Emendas/Emc/emc95.htm. Acesso em: 31 jul. 2020.

BRASIL. Emenda Constitucional no 103, de 12 de novembro de 2019. Brasília, DF:

Presidência da República, [2019]. Disponível em:

http://www.planalto.gov.br/ccivil 03/constituicao/Emendas/Emc/emc103.htm. Acesso em: 31 jul. 2020.

BRASIL. Lei no 13.429, de 31 de março de 2017. Brasília, DF: Presidência da República, [2017]. Disponível em: http://www.planalto.gov.br/ccivil 03/ ato20152018/2017/lei/l13429.htm. Acesso em: 31 jul. 2020. 
BRASIL. Lei no 13.467, de 13 de julho de 2017. Brasília, DF: Presidência da República, [2017]. Disponível em: http://www.planalto.gov.br/ccivil 03/ ato2015-2018/2017/lei/l13467.htm. Acesso em: 31 jul. 2020.

BRASIL. Lei no 13.874, de 20 de setembro de 2019. Brasília, DF: Presidência da República, [2019]. Disponível em: http://www.planalto.gov.br/ccivil 03/ ato20192022/2019/lei/L13874.htm. Acesso em: 31 jul. 2020.

BRASIL. Lei no 13.982, de 02 de abril de 2020. Brasília, DF: Presidência da República, [2020]. Disponível em: https://www.in.gov.br/en/web/dou/-/lei-n-13.982-de-2-de-abril-de-2020250915958. Acesso em: 31 jul. 2020.

BRASIL. Lei no 14.020, de 06 de julho de 2020. Brasília, DF: Presidência da República, [2020]. Disponível em: https://www.in.gov.br/en/web/dou/-/lei-n-14.020-de-6-de-julho-de-2020265386938. Acesso em: 31 jul. 2020.

BRASIL. Medida Provisória no 905, de 11 de novembro de 2019. Brasília, DF: Presidência da República, [2019]. Disponível em: http://www.planalto.gov.br/ccivil 03/ ato20192022/2019/Mpv/mpv905.htm. Acesso em: 31 jul. 2020.

BRASIL. Medida Provisória no 922, de 28 de fevereiro de 2020. Brasília, DF: Presidência da República, [2020]. Disponível em: http://www.planalto.gov.br/ccivil 03/ Ato20192022/2020/Mpv/mpv922.htm. Acesso em: 31 jul. 2020.

BRASIL. Medida Provisória no 927, de 22 de março de 2020. Brasília, DF: Presidência da República, [2020]. Disponível em: http://www.planalto.gov.br/ccivil 03/ ato20192022/2020/mpv/mpv927.htm. Acesso em: 31 jul. 2020.

BRASIL. Medida Provisória no 928, de 23 de março de 2020. Brasília, DF: Presidência da República, [2020]. Disponível em: http://www.planalto.gov.br/ccivil 03/ ato20192022/2020/Mpv/mpv928.htm. Acesso em: 31 jul. 2020.

BRASIL. Medida Provisória no 936, de 01 de abril de 2020. Brasília, DF: Presidência da República, [2020]. Disponível em: http://www.planalto.gov.br/ccivil 03/ ato20192022/2020/mpv/mpv936.htm. Acesso em: 31 jul. 2020.

BRASIL. Medida Provisória no 937, de 02 de abril de 2020. Brasília, DF: Presidência da República, [2020]. Disponível em: http://www.planalto.gov.br/ccivil 03/ ato20192022/2020/Mpv/mpv937.htm. Acesso em: 31 jul. 2020.

BRASIL. Medida Provisória no 944, de 03 de abril de 2020. Brasília, DF: Presidência da República, [2020]. Disponível em: http://www.planalto.gov.br/ccivil 03/ Ato20192022/2020/Mpv/mpv944.htm. Acesso em: 31 jul. 2020. 
BRASIL. Medida Provisória no 945, de 04 de abril de 2020. Brasília, DF: Presidência da República, [2020]. Disponível em: http://www.planalto.gov.br/CCIVIL 03/ Ato20192022/2020/Mpv/mpv945.htm. Acesso em: 31 jul. 2020.

BRASIL. Medida Provisória no 946, de 07 de abril de 2020. Brasília, DF: Presidência da República, [2020]. Disponível em: http://www.planalto.gov.br/ccivil 03/ ato20192022/2020/mpv/mpv946.htm. Acesso em: 31 jul. 2020.

BRASIL. Ministério da Economia. Secretaria Especial de Previdência e Trabalho. Portaria no 16.655, de 14 de julho de 2020. Diário Oficial da União: Edição: 133-A, Seção 1 - Extra, Brasília, DF, p. 01, 14 julho 2020.

BRASIL. Supremo Tribunal Federal. Medida Cautelar na Ação Declaratória de Constitucionalidade 58. Relator: Min. Gilmar Mendes, 27 de junho de 2020. Disponível em: http://portal.stf.jus.br/processos/downloadPeca.asp?id=15343656233\&ext=.pdf. Acesso em: 15 set. 2020.

BRASIL. Supremo Tribunal Federal. Referendo na Medida Cautelar na Ação Direta de Inconstitucionalidade 6342. Relator: Min. Marco Aurélio, 29 de abril de 2020. Disponível em: https://jurisprudencia.stf.jus.br/pages/search/sjur436234/false. Acesso em: 04 jan. 2021.

BRASIL. Supremo Tribunal Federal. Referendo na Medida Cautelar na Ação Direta de Inconstitucionalidade 6363. Relator: Min. Ricardo Lewandowski, 17 de abril de 2020. Disponível em: https://jurisprudencia.stf.jus.br/pages/search/sjur436850/false. Acesso em: 04 jan. 2021.

BRASIL. Supremo Tribunal Federal. Arguição de Descumprimento de Preceito Fundamental 324. Relator: Min. Roberto Barroso, 30 de agosto de 2018. Disponível em: http://redir.stf.jus.br/paginadorpub/paginador.jsp?docTP=TP\&doclD=750738975. Acesso em: 15 set. 2020.

BRASIL. Supremo Tribunal Federal. Recurso Extraordinário 958.252. Relator: Min. Luiz Fux, 30 de agosto de 2018. Disponível em:

http://redir.stf.jus.br/paginadorpub/paginador.jsp?docTP=TP\&doclD=750817537. Acesso em: 15 set. 2020.

BRIDI, Maria Aparecida; BOHLER, Fernanda Ribas; ZANONI, Alexandre Pilan. O Trabalho Remoto/Home-Office no Contexto da Pandemia Covid-19 - Parte I. Relatório de Pesquisa. Publicado pela REMIR - Rede de Estudos e Monitoramento Interdisciplinar da Reforma Trabalhista em 24 de julho de 2020. Disponível em:

https://www.eco.unicamp.br/remir/images/Artigos 2020/RELATRIO DE DIVULGAO DA PE SQUISA SOBRE O TRABALHO REMOTO.pdf. Acesso em: 26 jul. 2020. 
CASTEL, Robert. As metamorfoses da questão social: Uma crônica do salário. Petrópolis: Vozes, 1998.

CAVALLAZZI, Rosângela Lunardelli; SILVA, Sayonara Grillo Coutinho Leonardo da. Políticas de austeridade no Brasil contemporâneo: retrocessos laborais e consumeristas (2017-2019).

Revista de Direito do Consumidor, ano 28, v. 126, nov./dez. 2019.

CAVALLINI, Marta. Com pandemia, fechamento de vagas formais atinge mais quem ganha de 1 a 2 salários mínimos. G1, 12 de jul. de 2020. Disponível em:

<https://g1.globo.com/economia/concursos-e-emprego/noticia/2020/07/12/compandemia-fechamento-de-vagas-formais-atinge-mais-quem-ganha-de-1-a-2-salariosminimos.ghtml>. Acesso em: 12 de jul. de 2020.

CEFAÏ, Daniel. Como nos mobilizamos? A contribuição de uma abordagem pragmatista para a sociologia da ação coletiva. Dilemas - Revista de Estudos de Conflito e Controle Social, v. 2, n. 4, abr./jun. 2009.

DAMIÁN, Araceli. La pobreza de tiempo. Una revisión metodológica. Estudios demográficos y urbanos, v. 18, n. 01, jan./abr. 2003.

DARDOT, Pierre; LAVAL, Christian. A nova razão do mundo. Tradução de Mariana Echalar. São Paulo: Boitempo, 2016.

DELGADO, Gabriela Neves; AMORIM, Helder Santos. A legislação pandêmica e o perigoso regime de exceção aos direitos fundamentais trabalhistas. Revista Jurídica Trabalho e Desenvolvimento Humano, v. 3, 2020. Disponível em:

http://revistatdh.org/index.php/Revista-TDH/article/view/80. Acesso em: 14 dez. 2020.

DUTRA, Renata; MATOS, Bianca. A Terceirização, o STF e o Estado de Exceção. Teoria Jurídica Contemporânea, ano 04, v. 02, jul./dez. 2019.

ESTUDO da Fiocruz mostra que mulheres são mais afetadas pela pandemia. Rede Brasil Atual, São Paulo, 27 de mai. de 2020. Disponível em:

$<$ https://www.redebrasilatual.com.br/cidadania/2020/05/estudo-fiocruz-mulherespandemia/>. Acesso em: 27 de mai. de 2020.

FERREIRA, António Casimiro. Sociedade da Austeridade e Direito do Trabalho de Exceção. Lisboa: Vida Econômica, 2012.

FERREIRA, António Casimiro. The Politics of Austerity as Politics of Law. Oñati Socio-legal Series, v. 06, n. 03, set. 2016.

FILLEUL, Rodrigo Méndez; PELIZA, Eleonora. Efectos del Covid-19 en las relaciones laborales en América Latina: Argentina. Revista IDEIDES, n. 50, jul. 2020. 
FREITAS, Carlos Eduardo Soares; OLIVEIRA, Murilo Carvalho Sampaio; DUTRA, Renata Queiroz (orgs.). Reforma Trabalhista e Crise do Direito do Trabalho no Brasil: Apontamentos Críticos. Curitiba: Appris, 2020.

G1. Patrimônio dos super-ricos brasileiros cresce US\$ 34 bilhões durante a pandemia, diz Oxfam. Portal G1, 27 de jul. de 2020. Disponível em:

<https://g1.globo.com/economia/noticia/2020/07/27/patrimonio-dos-super-ricosbrasileiros-cresce-us-34-bilhoes-durante-a-pandemia-diz-oxfam.ghtml>. Acesso em: 28 de jul. de 2020.

GARCIA, Gustavo Filipe Barbosa. Prevalência de acordo individual sobre coletivo é questionável. Conjur (Consultor Jurídico), 2020a. Disponível em:

https://www.conjur.com.br/2020-mai-13/gustavo-garcia-acordo-individual-acordo-coletivo. Acesso em: 05 jul. 2020.

GARCIA, Gustavo Filipe Barbosa. Respeito à Constituição em situações de crise: redução salarial em decisão do STF. Conjur (Consultor Jurídico), 2020b. Disponível em:

https://www.conjur.com.br/2020-abr-27/barbosa-garcia-respeito-constituicao-situacoescrise. Acesso em: 05 jul. 2020.

GÊNERO E NÚMERO \& SOF - SEMPREVIVA ORGANIZAÇÃO FEMINISTA. Sem Parar: o trabalho e a vida das mulheres na pandemia. Publicado pela REMIR - Rede de Estudos e Monitoramento Interdisciplinar da Reforma Trabalhista em 03 de agosto de 2020. Disponível em:

https://www.eco.unicamp.br/remir/images/Artigos 2020/Relatorio Pesquisa SemParar.pdf . Acesso em: 20 ago. 2020.

HARVEY, David. Condição pós-moderna. Tradução de Adail Ubirajara Sobral e de Maria Stela Gonçalves. São Paulo: Loyola, 2008.

HARVEY, David. Política anticapitalista em tempos de COVID-19. In: DAVIS, Mike et al. Coronavírus e a luta de classes. S/I: Terra sem Amos, 2020b, p. 13-23.

HARVEY, David. Value in motion. New Left Review, n. 126, nov./dez. 2020a.

HERNÁNDEZ, Adoración Guamán. Los desafíos del derecho internacional del trabajo: la OIT enfrentada a la Lex Mercatoria (en tiempos de Covid-19). Revista de Derecho Social, n. 90, abr. 2020.

HONNETH, Axel. Luta por reconhecimento. A gramática moral dos conflitos sociais. São Paulo: Editora 34, 2003. 
Revista Jurídica Trabalho e Desenvolvimento Humano Procuradoria Regional do Trabalho da 15aㅡ Região

IBGE - Instituto Brasileiro de Geografia e Estatística. Pesquisa Pulso Empresa: Impacto da Covid-19 nas empresas. Publicado pelo IBGE em 16 de julho de 2020. Disponível em: https://agenciadenoticias.ibge.gov.br/media/com mediaibge/arquivos/548281f191c80ecbb b69846b0d745eb5.pdf. Acesso em: 17 jul. 2020.

KLEIN, Naomi. A doutrina do choque: a ascensão do capitalismo de desastre. Tradução de Vania Cury. Rio de Janeiro: Nova Fronteira, 2008.

KREIN, José Dari; OLIVEIRA, Roberto Véras de; FILGUEIRAS, Vitor Araújo (orgs.). Reforma trabalhista no Brasil: promessas e realidade. Campinas: Curt Nimuendajú, 2019.

LÓPEZ, Manuel-Carlos Palomeque. Un compañero de viaje historico del derecho del trabajo: la crisis economica. Revista de Política Social, n. 143, jul./set. 1984.

MARINO, Aluizio; KLINTOWITZ, Danielle; BRITO, Gisele; ROLNIK, Raquel; SANTORO, Paula; MENDONÇA, Pedro. Circulação para trabalho explica concentração de casos de Covid-19. Uol - A cidade é nossa, 2020. Disponível em:

https://raquelrolnik.blogosfera.uol.com.br/2020/06/30/circulacao-para-trabalho-explicaconcentracao-de-casos-de-covid-19/. Acesso em: 07 jul. 2020.

MASSAU, Guilherme; BAINY, André. Diálogo social, pacto social, reforma trabalhista e a proibição do retrocesso: um contrassenso prenunciado. Revista Jurídica Trabalho e Desenvolvimento Humano, v. 3, 2020. Disponível em:

http://revistatdh.org/index.php/Revista-TDH/article/view/61. Acesso em: 14 dez. 2020.

NEVES, Ianaira Barretto; SUTIL, Bruno. Algocracia e a racionalidade Neoliberal: Uma reflexão a partir da greve dos entregadores de aplicativos. Paper apresentado no 13응 Congresso Latino Americano de Varejo e Consumo - CLAV 2020, São Paulo, out. 2020. Publicado pela FGV - Fundação Getúlio Vargas. Disponível em: https://clav2020.fgv.br/. Acesso em: 24 nov. 2020.

OIT - ORGANIZAÇÃO INTERNACIONAL DO TRABALHO. Covid-19 and world of work: Impacts and responses. Publicado pela OIT em 18 de março de 2020. Disponível em:

https://www.ilo.org/global/about-the-ilo/WCMS 738753/lang--en/index.htm. Acesso em: 13 jul. 2020.

OLIVEIRA, Murilo Carvalho Sampaio; SANTOS, Tácio da Cruz; ROCHA, Wendy Santos. Os entregadores das plataformas digitais: controvérsias judiciais, autonomia, dependência e controle. Direito.UnB, v. 04, n. 02, mai.-ago. 2020.

OST, François. O tempo do direito. Tradução de Élcio Fernandes. Bauru: Edusc, 2005.

OXFAM INTERNACIONAL. Poder, lucros e a pandemia: da distribuição excessiva de lucros e dividendos de empresas para poucos para uma economia que funcione para todos.

SOARES, José Luis. O tempo e o Direito do Trabalho no Brasil da pandemia de Covid-19: quatro teses inspiradas em François Ost. Revista Jurídica Trabalho e Desenvolvimento Humano, Campinas, v. 4, p. 1-35, 2021. 
Relatório de Pesquisa. Publicado pela Oxfam Brasil em setembro de 2020. Disponível em: https://www.oxfam.org.br/justica-social-e-economica/poder-lucros-e-pandemia/. Acesso em: 20 set. 2020.

PŘIBÁŇ, Jiří. Introduction: Theorizing Liquid Modernity and Its Legal Context. In: PŘIBÁŇ, Jiří (ed.). Liquid Society and Its Law. Aldershot: Ashgate, 2007, p. 01-14.

REDE DE PESQUISA SOLIDÁRIA. Covid-19: Políticas Públicas e as Respostas da Sociedade. Boletim, n. 15, 10 jul. 2020.

SANTOS, Ana Clara Paiva; PEREIRA, langre; DINIZ, Ana Paola. A relevância da intervenção sindical e da negociação coletiva em tempos de Covid-19: uma análise crítica das Medidas Provisórias 927 e 936/2020 sob a ótica dos julgamentos do STF. In: Hirsch, Fábio Periandro (org.). Covid-19 e o Direito na Bahia. Salvador: Editora Direito Levado a Sério, 2020, p. 123149.

SENNET, Richard. A corrosão do caráter: As consequências pessoais do trabalho no novo capitalismo. Rio de Janeiro: Record, 2005.

SILVA, Sayonara Grillo Coutinho da; EMERIQUE, Lilian Balmant; BARISON, Thiago (orgs.). Reformas institucionais de austeridade, democracia e relações de trabalho. São Paulo: LTr, 2018.

SLOBODIAN, Quinn. Globalists: the end of empire and the birth of neoliberalism. Cambridge: Harvard University Press, 2018.

VANONI, Luciana Muniz. As disputas narrativas no direito e a terceirização no direito do trabalho. Dissertação (Mestrado em Direito). Universidade Estácio de Sá, Rio de Janeiro, 2019.

WAJCMAN, Judy. Digital technology, work extension and acceleration society. German Journal of Human Resource Management, v. 32, n. 03-04, mai. 2018. 